\title{
Fibroblast growth factor/fibroblast growth factor receptor system in angiogenesis
}

\author{
Marco Presta*, Patrizia Dell'Era, Stefania Mitola, Emanuela Moroni, \\ Roberto Ronca, Marco Rusnati
}

Unit of General Pathology and Immunology, Department of Biomedical Sciences and Biotechnology, School of Medicine, University of Brescia, Viale Europa 11, 25123 Brescia, Italy

Available online 2 February 2005

\begin{abstract}
Fibroblast growth factors (FGFs) are a family of heparin-binding growth factors. FGFs exert their pro-angiogenic activity by interacting with various endothelial cell surface receptors, including tyrosine kinase receptors, heparan-sulfate proteoglycans, and integrins. Their activity is modulated by a variety of free and extracellular matrix-associated molecules. Also, the cross-talk among FGFs, vascular endothelial growth factors (VEGFs), and inflammatory cytokines/chemokines may play a role in the modulation of blood vessel growth in different pathological conditions, including cancer. Indeed, several experimental evidences point to a role for FGFs in tumor growth and angiogenesis. This review will focus on the relevance of the FGF/FGF receptor system in adult angiogenesis and its contribution to tumor vascularization. (C) 2005 Elsevier Ltd. All rights reserved.
\end{abstract}

Keywords: Angiogenesis; Endothelium; FGF; FGF receptors; Tumor

\section{Introduction}

Angiogenesis, the process of new blood vessel formation from pre-existing ones, plays a key role in various physiological and pathological conditions, including embryonic development, wound repair, inflammation, and tumor growth [1]. The local, uncontrolled release of angiogenic growth factors and/or alterations of the production of natural angiogenic inhibitors, with a consequent alteration of the angiogenic balance [2], are responsible for the uncontrolled endothelial cell proliferation that takes place during tumor neovascularization and in angiogenesisdependent diseases [3].

Angiogenesis is a multi-step process that begins with the degradation of the basement membrane by activated endothelial cells that will migrate and proliferate, leading to the formation of solid endothelial cell sprouts into the stromal space. Then, vascular loops are formed and capillary

\footnotetext{
* Corresponding author. Tel.: +39030 3717 311; fax: +39030 3701157 . E-mail address: presta@med.unibs.it (M. Presta).
}

tubes develop with formation of tight junctions and deposition of new basement membrane [4].

Numerous inducers of angiogenesis have been identified, including the members of the vascular endothelial growth factor (VEGF) family, angiopoietins, transforming growth factor- $\alpha$ and $-\beta$ (TGF- $\alpha$ and $-\beta$ ), platelet-derived growth factor (PDGF), tumor necrosis factor- $\alpha$ (TNF- $\alpha$ ), interleukins, chemokines, and the members of the fibroblast growth factor (FGF) family.

Historically, a tumor angiogenic factor (TAF) was first isolated in 1971 from rat Walker 256 carcinoma [5]. TAF had a molecular weight of about $10 \mathrm{kDa}$ and consisted of $25 \% \mathrm{RNA}$, $10 \%$ proteins, and $58 \%$ carbohydrates, plus a possible lipid fraction. The 1980s saw for the first time the purification to homogeneity of pro-angiogenic proteins, the breakthrough coming as a result of the observation that endothelial cell growth factors showed a marked affinity for heparin $[6,7]$. This led to the identification, purification, and sequencing of the two prototypic heparin-binding angiogenic growth factors FGF1 and FGF2. Since then, 22 structurally-related members of the FGF family have been identified [8]. FGFs are pleiotropic factors acting on different cell types, including 
endothelial cells, following interaction with heparan-sulfate proteoglycans (HSPGs) and tyrosine kinase FGF receptors (FGFRs). To date, more than 1200 PubMed-referenced papers related to FGFs and FGFRs in endothelial cells and during neovascularization have been published. This review will focus on the role of the FGF/FGFR system in angiogenesis.

\section{Pro-angiogenic activity of FGFs}

As stated above, FGFs exert their biological activities by binding to high affinity tyrosine kinase FGFRs on the surface of target cells. In vitro, endothelial cells of different origin express FGFR1 $[9,10]$ and, under some circumstances, FGFR2 [11] whereas the expression of FGFR3 or FGFR4 has never been reported in endothelium.

Only a limited number among the 22 members of the FGF family have been investigated for their angiogenic potential in vitro and in vivo, the bulk of experimental data referring to the prototypic FGF1 and FGF2.

\subsection{In vitro effects on endothelial cells}

The necessity to study in detail the process of angiogenesis has led to the isolation and in vitro culture of endothelial cells [12]. A high degree of heterogeneity has been observed for endothelial cells isolated from different tissues and/or animal species. Also, significant differences exist between large-vessel and microvascular endothelium [13-15]. Nevertheless, the bulk of experimental evidence indicate that different members of the FGF family, mostly FGF1 and FGF2, can induce in vitro a complex "proangiogenic phenotype" in endothelial cells (Fig. 1) that recapitulates several aspects of the in vivo angiogenesis process, including the modulation of endothelial cell proliferation, migration, protease production, integrin and cadherin receptor expression, and intercellular gap-junction communication (summarized in [10]).

\subsubsection{Endothelial cell proliferation}

Activation of FGFR1 or FGFR2 by angiogenic FGFs (including FGF1, FGF2, and FGF4) leads to endothelial cell proliferation [16]. Recently, also the FGF8b isoform has been shown to stimulate endothelial cell proliferation in vitro [17]. FGFR engagement involves the activation of several parallel signaling pathways as a consequence of receptor autophosphorylation followed by recruitment of Shc, FRS2, and Crk adaptor molecules (for a review see [16]). Interestingly, besides activation of the MAPK signaling pathway, a long lasting activation of protein kinase $\mathrm{C}$ (PKC) is required for FGF2 to exert a full mitogenic response in endothelial cells [18]. PKC downregulation abolishes FGF2-induced endothelial cell proliferation but not urokinase-type plasminogen activator (uPA) upregulation. Also, autophosphorylation of distinct tyrosine residues in FGFR1 mediate the mitogenic and uPAinducing activity of FGF2 [19], suggesting that the two biological responses can be dissociated at the molecular level.

\subsubsection{Extracellular matrix degradation}

Extracellular matrix (ECM) degradation represents an important step during the first phases of the angiogenesis process. The plasmin-plasminogen activator system and matrix metalloproteinases (MMPs) cooperate in this degradation [20]. uPA converts plasminogen into plasmin, a serine protease that degrades fibrin and other matrix proteins, and activate several MMPs, including stromelysin1 (MMP-3), collagenase-1 (MMP-1), type IV collagenases (MMP-2 and MMP-9) [21].

FGF1, FGF2, and FGF4 upregulate uPA and MMPs production in endothelial cells. Also, FGFs modulate the expression of uPA receptor on the endothelial cell surface, thus allowing the localization of the proteolytic activity at the leading edge of the cell at the front of migration [22]. Furthermore, FGF1 and FGF2 induce the expression of the plasminogen activator inhibitor (PAI)-1 in cultured

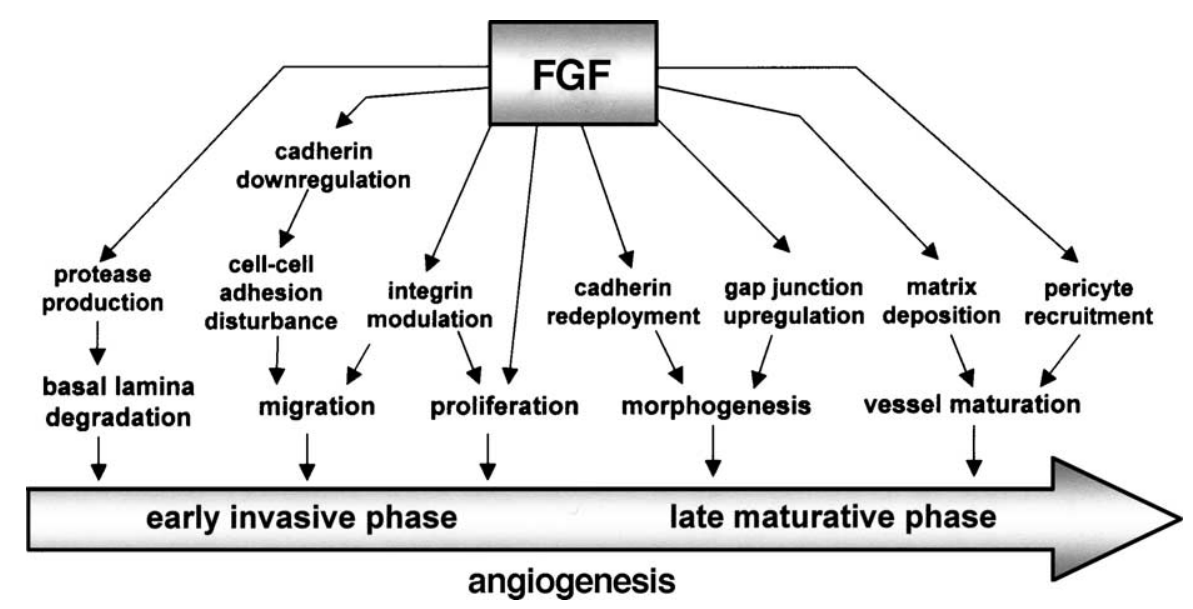

Fig. 1. Schematic representation of the events triggered by FGFs in endothelial cells that contribute to the acquisition of the angiogenic phenotype in vitro and to neovascularization in vivo. 
endothelial cells leading to a fine modulation of the proteolytic balance [23-25].

Stimulation of endothelial cells by FGF2 causes also the shedding of cell surface membrane vesicles containing MMP-2 and MMP-9 together with the two MMP inhibitors TIMP-1 and TIMP-2. These vesicles stimulate capillary-like structure formation when added to endothelial cells seeded on a solubilized basement membrane preparation (Matrigel) [26].

\subsubsection{Endothelial cell migration}

FGF1 and FGF2 [27,28], the FGF8b isoform [17], and FGF10 [29] stimulate chemotaxis and/or chemokinesis in endothelial cells. Similar to cell proliferation, the chemotactic effect of FGF2 requires the activation of the MAPK signaling pathway [30] and is abolished by PKC down-regulation [31]. The capacity of FGFR1 to mediate chemotaxis resides in the amino acid stretch 759-773 of its cytoplasmic tail [32]. However, the biological response is independent of tyrosine phosphorylation and requires the activation of a Wortmannin-sensitive pathway [32]. Expression of a kinase-inactive c-Fes mutant interferes with FGF2-induced chemotaxis in endothelial cells [33]. Moreover, FGF2-mediated chemotaxis on fibronectincoated substrata can be attenuated by $\alpha_{\mathrm{v}} \beta_{3}$ integrin inhibitors [34].

The angiogenesis process can be mimicked in vitro by culturing endothelial cells on a layer of or within a 3D permissive matrix substrate [35]. Under these conditions, endothelial cells invade the substratum and organize capillary-like structures with a hollow lumen [36]. FGF2 enhances this response in type I collagen gel [37] possibly via a p38-dependent signaling pathway [38]. Endothelial cell morphogenesis can be induced by FGF2 also using three-dimensional fibrin gels [39]. Invasion of fibrin matrix can be modulated by TGF $\beta-1[39,40]$ and is mediated by CD44 [41] and integrin receptors [42].

\subsubsection{Modulation of integrins, cell-cell adhesion receptors, and matrix deposition}

Endothelial cell migration and proliferation are limited by lateral cell-cell adhesion and ECM interactions [43] that, in turn, are mediated by cadherin and integrin receptors. Accordingly, FGF2-mediated adhesion and migration of endothelial cells onto type I collagen depends on both integrin expression and cell density [44]. Interestingly, FGF2 regulates the expression of different integrins, including $\alpha_{v} \beta_{3}$ [45-47], and cadherins [43,48] in a complex fashion. Indeed, a brief exposure to FGF2 hampers endothelial cell-cell junctions whereas a prolonged exposure to the growth factor promotes a slow temporal redistribution of the junctional adhesion proteins, platelet/ endothelial cell adhesion molecule (PECAM/CD31), vascular/endothelial cadherin, and plakoglobin. These data indicate that FGFs can promote both endothelial cell scattering, that is required during the first steps of the angiogenic process, and the formation of the cell-cell interactions required to vessel maturation [43] (Fig. 1). A similar mechanism of regulation may exist also for the interaction with the ECM that surrounds the endothelium. Indeed, FGFs initially promote the disruption of the basal lamina by inducing protease production. Lately, FGFs may induce the production of various ECM components by endothelial cells [49], contributing to the maturation of the new vessels (Fig. 1).

\subsubsection{Endothelial cell morphogenesis}

FGF2 [50] and FGF8b [17] can enhance endothelial cell reorganization on Matrigel. The process requires the activation of the proteolytic machinery, including type IV collagenase(s) and TIMPs production [51] as well as UPA and PAI-1 upregulation [52], $\alpha_{6} \beta_{1}$ integrin receptor engagement [53], PECAM-1 [54], and activation of the small GTPase Rac [55]. Moreover, FGF2-mediated endothelial cell morphogenesis requires signals via VEGF receptor-1 (VEGFR-1) [56], underlying the cross-talk between FGF and VEGF signaling (see below).

\subsubsection{Autocrine, intracrine, paracrine mechanisms of action of FGFs in endothelial cells}

FGFs can exert their effects on endothelial cells via a paracrine mode consequent to their release by tumor and stromal cells and/or by their mobilization from the ECM. On the other hand, FGF2 may also play an autocrine role in endothelial cells, as suggested by in vitro and in vivo experimental evidences (see [57] and references therein). Accordingly, FGF2 has been implicated in the pathogenesis of lesions of endothelial cell origin, including Kaposi's sarcoma [58] and hemangiomas [59]. Also, the $f g f 4$ gene is overexpressed in HHV8-positive Kaposi's sarcoma [60]. To assess the biological consequences of endothelial cell activation by endogenous FGFs, we originated a stable mouse aortic endothelial cell line transfected with a human FGF2 cDNA [57]. FGF2 transfectants show an invasive and morphogenetic behavior in vitro. In vivo, they are angiogenic, cause the formation of opportunistic vascular tumors in nude mice, and induce hemangiomas in the chick embryo [61]. Accordingly, FGF2 transfection affects the expression of numerous genes implicated in the modulation of cell cycle, differentiation, cell adhesion, and stress/survival [62]. Some of these genes are similarly modulated in vitro and in vivo by administration of the recombinant growth factor [62].

A transformed morphology and an increased proliferative capacity is also observed for FGF4-transfected mouse aortic endothelial cells. However, FGF4 transfectants, although angiogenic in the chorioallantoic membrane (CAM) assay, show a limited capacity to growth under anchorageindependent conditions, to invade 3D fibrin gel, to undergo morphogenesis in vitro, and to induce hemangiomas in the chick embryo [11].

The observed differences between FGF2 and FGF4 transfectants may reflect differences in the intracellular and/ 
or extracellular fate of the two growth factors. The singlecopy human $f g f 2$ gene encodes multiple FGF2 isoforms with molecular weight ranging from 18 to $24 \mathrm{kDa}$. Both low and high molecular weight FGF2 isoforms show angiogenic activity [63]. At variance with other FGFs, FGF2 isoforms lack a leader sequence for secretion and are released in limited amounts by an alternative secretion pathway [64] or via membrane vesicle shedding [65]. Experimental evidences point to different functions of FGF2 isoforms in transfected endothelial cells [66], possibly related to differences in their subcellular localization and release. Indeed, high molecular weight FGF2 isoforms contain a nuclear localization sequence and are mostly recovered in the nucleus whereas the $18 \mathrm{kDa}$ FGF2 isoform is mostly cytosolic [67]. The constitutive overexpression of high molecular weight FGF2 isoforms leads to cell immortalization whereas $18 \mathrm{kDa}$ FGF2 overexpression induces a transformed phenotype [68]. In contrast, FGF4 is efficiently released and does not play an intracellular role [69]. On this basis, the biological differences observed between FGF2 and FGF4 endothelial cell transfectants may reflect differences in the intracrine and/or autocrine activities of the two growth factors. Accordingly, transfection with a secreted form of FGF1 leads to altered morphology and increased motility in endothelial cells [70].

Taken together, these data suggest that endogenous FGFs produced by endothelial cells may play important autocrine, intracrine, or paracrine roles in angiogenesis and in the pathogenesis of vascular lesions.

\subsection{In vivo effects and experimental angiogenesis assays}

FGFR1 is expressed by endothelial cells in vivo [71-73], even though a detailed analysis of FGFR expression patterns in vivo deserves further investigation. To this respect, disruption of the genes encoding for the different FGFRs in mice is not informative. Indeed, $f g f r 1$ null embryos are developmentally retarded and dye during gastrulation, the early embryonic lethality occurring prior to a stage in which the role of FGFR1 in blood vessel development can be evaluated $[74,75]$. However, adenovirus-mediated expression of dominant-negative FGFR1 results in a significant impairment of blood vessel development and maintenance in mouse embryos cultured in vitro [76]. Fgfr2 mutation results in a later embryonic lethality characterized by the lack of a functional placenta and limb buds [77]. Fgfr3-deficient mice are normal during gestation and exhibit bone alterations during postnatal development [78]. Finally, Fgfr4-null animals are developmentally normal [79].

In keeping with the expression of FGFR1 on endothelial cells in vivo, the angiogenic activity of recombinant FGF1 and FGF2 proteins has been demonstrated in various experimental models, including the chick embryo CAM [80], the avascular rabbit [81] or mouse [82] cornea, and subcutaneous Matrigel injection [83]. Similarly, the delivery of either one of the two growth factors via retroviral, adenoviral, lentiviral, and adeno-associated viral vectors or via implantation of different FGF-overexpressing cell transfectants result in a potent angiogenic response in various experimental animal models (see below).

The CAM assay is a well-established assay for studying the effects of growth factors on blood vessel growth [80]. As compared to the application on the CAM of a single bolus of recombinant FGF2, cell implants overexpressing the growth factor allows the continuous delivery of FGF2 produced by a limited number of cells, thus mimicking more closely the initial stages of tumor angiogenesis [84]. Indeed, the release of $1.0 \mathrm{pg}$ FGF2 per day from viable cells triggers an angiogenic response quantitatively similar to that elicited by $1.0 \mu \mathrm{g}$ of the recombinant molecule [84]. Also, neutralizing anti-FGF2 antibodies prevent CAM neovascularization, supporting the key role of endogenous FGF2 in the development of vascular system in avian embryo [85]. Accordingly, FGFRs are expressed in the CAM until E10, when the angiogenic process is switched off [86].

In contrast with the potent angiogenic response elicited by exogenous FGF2 in different in vitro and in vivo models, the role of endogenous FGF2 in angiogenesis remains uncertain. Indeed, $f g f 2$ knockout mice are morphologically normal [87] and do not show differences in neovascularization following injury [88] or hypoxia [89]. Conversely, transgenic overexpression of FGF2 does not result in spontaneous or inherent vascular defects, even though an amplified angiogenic response can be observed after wounding or s.c. implantation of a Matrigel plug [90]. The apparently normal vascularization in $f g f 2^{-l-}$ mice as well as in double $f g f 2^{-/-} \mid f g f 1^{-/-}$mice may reflect the wide redundancy in the FGF family [91] and the contribution to angiogenesis of several other angiogenic growth factors, including VEGF (see below).

Angiogenic activity has been shown also for other members of the FGF family. FGF3/int-2 oncogene expressing human epithelial mammary cells or their conditioned culture medium exert a potent angiogenic response in the $\mathrm{CAM}$ assay. The same conditioned medium triggers angiogenesis also in the mesentery of i.p. injected rats [92]. Analysis of mammary glands from $f g f 4$ transgenic mice confirmed preliminary in vitro data about the angiogenic properties of FGF4 mediated through VEGFA upregulation [93]. The pro-angiogenic activity of FGF4 is confirmed by the angiogenic effect exerted by FGF4encoding adenovirus in a rabbit hind limb ischemia model [94] and by FGF4-transfected endothelial cells in the CAM assay [11]. Intracoronary gene transfer of FGF5 increases blood flow and contractile function in ischemic heart possibly related to an increased vascularization [95]. Subnanomolar concentrations of FGF7/KGF induce neovascolarization in the avascular rat cornea [29]. FGF8b elicits an angiogenic response in the CAM assay [17] significantly enhanced by heparin co-administration (Presta, unpublished observations). Transient expression of FGF9 in transgenic mice results in alterations of retinal pigment 
epithelium possible related to alterations of the choroidal vasculature [96]. Finally, FGF10, which is structurally related to FGF7, elicits a pro-migratory effect on capillary endothelial cells, suggesting a possible pro-angiogenic activity in vivo [29].

\subsection{FGF/VEGF cross-talk}

For many years FGF1 and FGF2 occupied a central stage in the angiogenesis field. Then, the VEGF family of angiogenic growth factors came to the limelight after the discovery of their pivotal role in vasculogenesis and angiogenesis during embryonic development and under numerous physiologic and pathologic conditions in adults [97]. The VEGF family comprises six members (VEGF-A denoting the originally identified VEGF) that differently interact with three cell surface tyrosine kinase VEGFRs. To date, VEGF-A/VEGFR-2 interaction appears to play a major role in blood vessel angiogenesis whereas VEGF-C and -D are mainly involved in lymphangiogenesis by interacting with VEGFR-3 expressed on lymphatic endothelium [97].

An intimate cross-talk exists among FGF2 and the different members of the VEGF family during angiogenesis, lymphangiogenesis, and vasculogenesis. Several experimental evidences point to the possibility that FGF2 induces neovascularization indirectly by activation of the VEGF/ VEGFR system. Indeed: (i) VEGFR-2 antagonists inhibit both VEGF and FGF2-induced angiogenesis in vitro and in vivo [98]; (ii) expression of dominant-negative FGFR1 or FGFR2 in glioma cells results in a decrease in tumor vascularization paralleled by VEGF down-regulation [99]; (iii) both endogenous and exogenous FGF2 modulate VEGF expression in endothelial cells [82]; (iv) in the mouse cornea, the quiescent endothelium of vessels of the limbus express both VEGF mRNA and protein only after FGF2 treatment. In the same model, systemic administration of anti-VEGF-A neutralizing antibodies dramatically reduces FGF2-induced vascularization [82]; (v) VEGFR-1-blocking antibodies or the expression of a dominant-negative VEGFR-1 result in a significant reduction of FGF2-induced cell extensions and capillary morphogenesis [56]; (vi) FGF2 upregulates the expression of both FGFRs and VEGFRs in endothelial cells [100].

On the other hand, endothelial cell tube formation stimulated by VEGF in murine embryonic explants depends on endogenous FGF2 [101]. Also, FGF2 and VEGF may exert a synergistic effect in different angiogenesis models [102-104] even though this may not be the case when the two factors are applied onto the chick embryo CAM [105].

Recently, we analyzed the vascularization of xenografts originating from different clones of the same human tumor cell line but differing for the expression of VEGF and/or FGF2 [106]. The two growth factors exert a synergistic effect on tumor blood vessel density. However, FGF2 and VEGF exert a different impact on blood vessel maturation and functionality (see below). Accordingly, the study of the transcriptional changes occurring in cultured endothelial cells revealed that, together with a cluster of angiogenesisrelated genes that were similarly modulated by FGF2 and VEGF, the two growth factors affected the expression of distinct subsets of transcripts $[107,108]$. Accordingly, FGF2, but not VEGF, induces the upregulation of telomerase activity in endothelial cells, thus preventing the early onset of senescence [109]. Distinct patterns of vascular morphology upon FGF2 or VEGF stimulation are described also in the quail embryo CAM assay [86]. Finally, increased endothelial fenestration is observed in the blood vessels of the chick embryo CAM stimulated by VEGF-overexpressing cells, but not by FGF2-overexpressing cells, despite the quantitatively similar angiogenic response elicited by the two transfectants [84].

Thus, FGF2 may require the activation of the VEGF/ VEGFR system for promoting angiogenesis. Conversely, VEGF may require FGF2 for exerting its angiogenic potential under defined experimental conditions. Nevertheless, the two growth factors retain distinct biological properties exerting different biological effects on endothelial cells during angiogenesis.

Lymphatic system drains extravasated fluid, proteins, and immune cells, and transport them back to the venous circulation via the collecting lymphatic vessels and the thoracic duct. In tumors the development of the lymphatic network may play a critical role in facilitating the metastatic spread of malignant cells. Recent data demonstrate that a FGF/VEGF cross-talk may occur also during lymphangiogenesis. FGF2 pellets implanted in the mouse cornea trigger both angiogenesis and lymphangiogenesis, lymphatic vessels being more sensitive than blood vessels to FGF2 [110]. However, the lymphangiogenic activity of FGF2 is mediated by endogenous VEGF-C and VEGF-D upregulation, leading to VEGFR-3 activation [111]. Interestingly, no endothelial fenestration was observed in FGF2, VEGF-A, or VEGF-C-induced lymphatic vessels [112].

The VEGF/VEGFR system is essential for the development of embryonic vasculature [113]. The situation is much less well-defined for the FGF/FGFR system. As stated above, the phenotype of $f g f r$ knockout mice is scarcely informative even though adenovirus-drive dominant-negative FGFR 1 expression leads to severe vascular alterations in mouse embryos [76]. Also, FGF2 promotes the proliferation and differentiation of VEGFR-2 $2^{+}$hemangioblast precursors from the mesoderm [114]. In embryoid bodies, embryonic stem cells can differentiate into a variety of cell lineages, including endothelial cells [115]. In this model, both VEGF and FGF2 lead to improved angioblast survival but only VEGF supports the formation of primitive endothelial tubes [116]. Also, in embryoid bodies in which VEGF/VEGFR function is impaired, FGF2 stimulates the formation of endothelial cell clusters that fail to develop into primitive vessels. In contrast, VEGF induces the formation of a characteristic vascular plexus also in $f g f r 1^{-1-}$ embryoid bodies [117]. 


\section{FGF interaction with endothelial cell surface, extracellular matrix, and free molecules}

As stated above, FGFs interact with signaling FGFRs expressed on the endothelial cell surface. However, various other binding partners can affect the biological activity and angiogenic potential of FGFs (Fig. 2). These molecules can interact with FGFs in the extracellular environment, thus modulating their bioavailability, stability, local concentration, interaction with endothelial receptors, and intracellular fate. The complexity of this network of interactions is manifold: (i) FGF-binding molecules, heterogeneous in nature, are present in the blood stream or in body fluids as free molecules or associated to ECM; (ii) under different conditions, certain FGF-binding molecules may be present as free, ECM-associated, or cell membrane-associated molecules, possibly exerting different effects on FGF activity (see below); (iii) endothelial cell receptors distinct
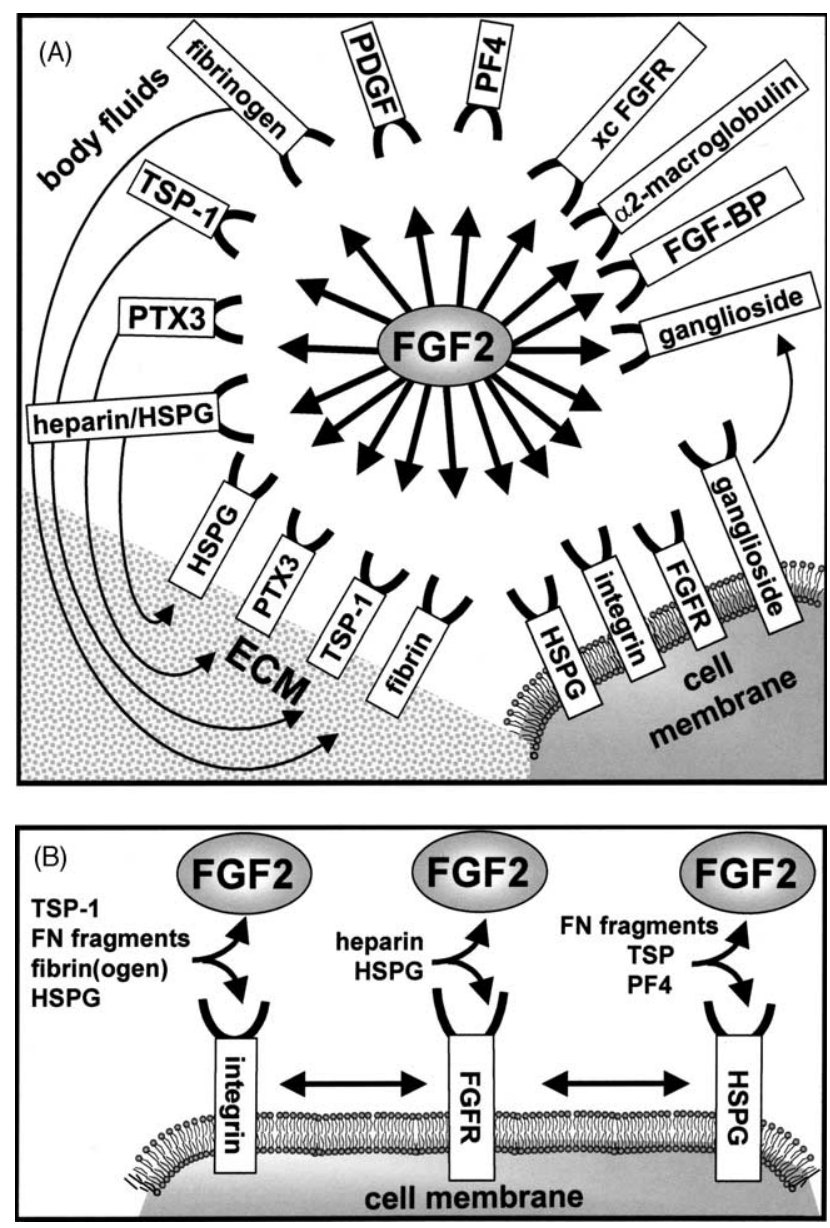

Fig. 2. FGF2-binding molecules. (A) Proteins, polysaccharides, and lipids present as free molecules in body fluids, associated to ECM, or anchored to endothelial cell membrane bind FGF2. Some of these molecules can change their status from an immobilized to a free form (arrows) exerting opposite effects on the biological activity of FGFs. (B) Some FGF binders are also able to interact with FGF-binding sites/receptors present on the surface of endothelial cells, possibly exerting agonist/antagonist effects (see text for further details). from FGFRs may activate signal transduction pathways complementary to those activated by FGFRs; (iv) some FGF-binding molecules can also bind FGFRs, leading to possible agonist/antagonist effects.

FGF2 is present in blood at concentrations equal to $0.6 \mathrm{pM}$ in physiological conditions and up to $6.0 \mathrm{pM}$ under different pathological conditions [see [118] and references therein] whereas its binding partners are present at concentrations that are up to $1,000,000$ times higher (Table 1). Thus, FGFs should exist mainly as immobilized molecules bound to the ECM and/or cell surface or as circulating complexes. The relative concentrations of the various FGF-binders may change greatly during different physio-pathological conditions, shifting the binding of FGFs from one ligand to another with repercussion on their bioavailability, endothelial cell interactions, and biological activities. Since the bulk of experimental data refer to the interaction of FGF2 with a number of extracellular molecules other than FGFRs, we will focus on FGF2 and its binding partners, even though many of the interactions described below may apply also to other members of the FGF family and, possibly, to other cytokines.

\subsection{Cell surface and ECM components}

\subsubsection{Heparin and HSPGs}

FGFs are heparin-binding proteins. Heparin is a negatively charged glycosaminoglycan released in the blood stream during inflammation. However, FGFs are more likely to interact with the heparan sulfate glycosaminoglycan chains attached to HSPG core proteins. HSPGs are expressed on the surface of almost all the cell types, including the endothelium, where they can be found as membrane-associated receptors, as ECM components, or released as free molecules [119]. HSPGs modulate angiogenesis by interacting with pro and negative regulators [120]. In particular, heparin/HSPGs bind FGF1, FGF2, FGF4, FGF7, and FGF8, modulating their biological activities in vitro and in vivo [121]. The interaction of heparin/HSPGs with FGFs occurs with low affinity and is mediated by the negatively charged sulfated groups of the saccharidic chain [122] that bind to basic amino acid motifs [123].

The alternative binding of FGFs to heparin, or to free, ECM-associated, or cell-surface HSPGs results in a fine control of the bioavailability and endothelial cell interaction of these growth factors (reviewed in [121]). In general, free heparin/HSPGs sequester FGFs in the extracellular environment and act as FGF antagonists. On the contrary, cellassociated HSPGs can directly activate a signal transduction pathway in response to FGF2 [124], promote FGF2 internalization [125,126], and are required for a correct presentation of FGFs to FGFRs, leading to the formation of productive HSPGs/FGF/FGFR ternary complexes [121]. Finally, HSPGs of the ECM act as a reservoir for FGF2 that reaches higher local concentrations and sustains the long- 
Table 1

FGF2-binding molecules

\begin{tabular}{|c|c|c|c|c|}
\hline Endothelial cell surface receptors & FGF2 affinity $\left(K_{\mathrm{d}}\right)$ & Reference & Number per cell & Reference \\
\hline FGFR & $20.0 \mathrm{pM}$ & {$[125]$} & $\sim 10-20,000$ & {$[125]$} \\
\hline$\alpha_{v} \beta_{3}$ integrin & $6.5 \mathrm{nM}^{\mathrm{b}}$ & & $\sim 1 \times 10^{6 \mathrm{c}}$ & {$[141]$} \\
\hline HSPGs $^{\mathrm{a}}$ & $413.0 \mathrm{nM}$ & {$[125]$} & $\sim 0.5-1.0 \times 10^{6 \mathrm{~d}}$ & [125] \\
\hline Gangliosides & $3.0 \mathrm{nM}$ & {$[148]$} & N.D. & \\
\hline Free molecules & FGF2 affinity $\left(K_{\mathrm{d}}\right)$ & Reference & Blood concentration & Reference \\
\hline$\overline{\text { FGF-binding protein }}$ & $10 \mathrm{nM}$ & {$[153]$} & N.D. & \\
\hline Free gangliosides & $6.0 \mu \mathrm{M}$ & {$[147]$} & $10 \mu \mathrm{M}^{\mathrm{e}}$ & [249] \\
\hline Heparin & $42.0 \mathrm{nM}$ & [139] & N.D. & \\
\hline $\mathrm{TSP}^{\mathrm{a}}$ & $30.0 \mathrm{nM}$ & {$[150,151]$} & $0.26-15.0 \mathrm{nM}^{\mathrm{f}}$ & {$[250]$} \\
\hline $\mathrm{PTX}^{\mathrm{a}}$ & $10.0 \mathrm{nM}$ & {$[166]$} & $0.16-0.36 \mathrm{nM}^{\mathrm{g}}$ & [251] \\
\hline Fibrin $(\text { ogen })^{\mathrm{a}}$ & $1.3-260.0 \mathrm{nM}^{\mathrm{h}}$ & [252] & $7.0 \mu \mathrm{M}$ & [118] \\
\hline$\alpha_{2}$ macroglobulin & $62.0 \mathrm{nM}$ & {$[162]$} & $5.0 \mu \mathrm{M}$ & {$[162]$} \\
\hline $\mathrm{xcFGFR} 1^{\mathrm{a}}$ & $5.0-10.0 \mathrm{nM}$ & {$[158]$} & N.D. & \\
\hline PDGF & $23.0 \mathrm{nM}$ & {$[168]$} & $74.0-204.0 \mathrm{nM}^{\mathrm{i}}$ & {$[253]$} \\
\hline PF4 & $37.0 \mathrm{nM}$ & [170] & $5.0-8.7 \mathrm{nM}^{\mathrm{j}}$ & [254] \\
\hline
\end{tabular}

Affinity of different FGF2-binding partners, their number per cell or their blood concentration are indicated. Please note that FGF2 concentration in blood may range between 0.6 and $6.0 \mathrm{pM}$ (see text). N.D.: not determined.

${ }^{a}$ These molecules can also be found associated to ECM.

b Our unpublished data.

c Value calculated by using radiolabeled fibronectin.

d These values refer to the number of FGF2-binding sites, as a single HSPG receptor can bind multiple FGF2 molecules.

e Total serum sialic acid content in healthy subjects.

${ }^{\mathrm{f}}$ Values measured in the absence or in the presence of platelet activation.

$g$ Values measured in the absence or in the presence of acute myocardial infarction.

$\mathrm{h}$ The two values are representative of the biphasic nature of the binding.

${ }^{\mathrm{i}}$ Values measured in healthy and tumor-bearing individuals.

$\mathrm{j}$ Values measured in health and coronary disease.

term stimulation of endothelial cells [127]. A schematic representation of the effects exerted by the heparin/HSPGs system on the biology of FGFs is shown in Fig. 3.

The binding of FGFs to different HSPGs may have different biological consequences. This is the case for syndecan, betaglycan, and perlecan, all able to bind FGF2 but with different effects. For instance, syndecan inhibits the mitogenic activity of FGF2 whereas perlecan promotes FGF2-induced cell proliferation and angiogenesis (reviewed in [128]). It is interesting to note that modifications of HSPGs composition can regulate the sensitivity of the cell to different FGFs [129] and that FGFs themselves can modulate HSPG synthesis [130].

Also, FGF2 regulates the synthesis of HSPGs as well as the production of protease/glycosidase that digest the core protein/saccharidic chains of HSPGs inducing the mobilization of free HSPGs/HS chains [131]. ECM degradation can lead to mobilization of entrapped FGF2 with consequent activation of an angiogenic response [132].

The capacity of various angiogenic factors, including FGFs, to bind heparin/HS indicates that molecules able to interfere with this interaction may act as angiogenesis inhibitors. The ability of low molecular weight heparin fragments to reduce the angiogenic activity of FGF2 and VEGF support this hypothesis. On this basis, several heparinlike anionic molecules and heparin derivatives have been developed as possible candidate drugs (reviewed in [128]).

\subsubsection{Integrin receptors}

Integrins are transmembrane, adhesion receptor heterodimers comprised of $\alpha$ and $\beta$ subunits. The combination of different subunits originates distinct integrins that mediate cell adhesion to a variety of adhesive proteins of the ECM [133]. Integrins regulates also the response of endothelial cells to soluble growth factors, including FGF2 [134], but the molecular mechanism(s) of this regulation are not fully elucidated. $\alpha_{\mathrm{v}} \beta_{3}$ integrin is expressed on endothelial cells where it plays a central role in neovascularization. For this reason it has been considered as a target for the development of anti-cancer therapies [135].

Similar to classical adhesive proteins, FGF2 binds $\alpha_{\mathrm{v}} \beta_{3}$ [136]. Consequently, immobilized FGF2 promotes endothelial cell adhesion and spreading, leading to uPA upregulation, cell migration, proliferation, and morphogenesis [137]. $\alpha_{v} \beta_{3} / F G F 2$ interaction and endothelial cell adhesion to immobilized FGF2 lead to the assembly of focal adhesion plaques containing $\alpha_{\mathrm{v}} \beta_{3}$ and FGFR1, whose presence is an absolute requirement for the activation of $\mathrm{ERK}_{1 / 2}$ and cell proliferation [137]. Accordingly, a direct $\alpha_{\mathrm{v}} \beta_{3} /$ FGFR1 interaction is required for a full response to FGF2 [138].

Endothelial cell adhesion and activation by immobilized FGF2 may have relevance in vivo. Indeed, as stated above, FGF2 accumulates as an immobilized protein in the ECM, mainly by binding to HSPGs. Relevant to this point, heparinbound FGF2 retains it cell-adhesive capacity [139]. Also, 
(A) sequestration FGF
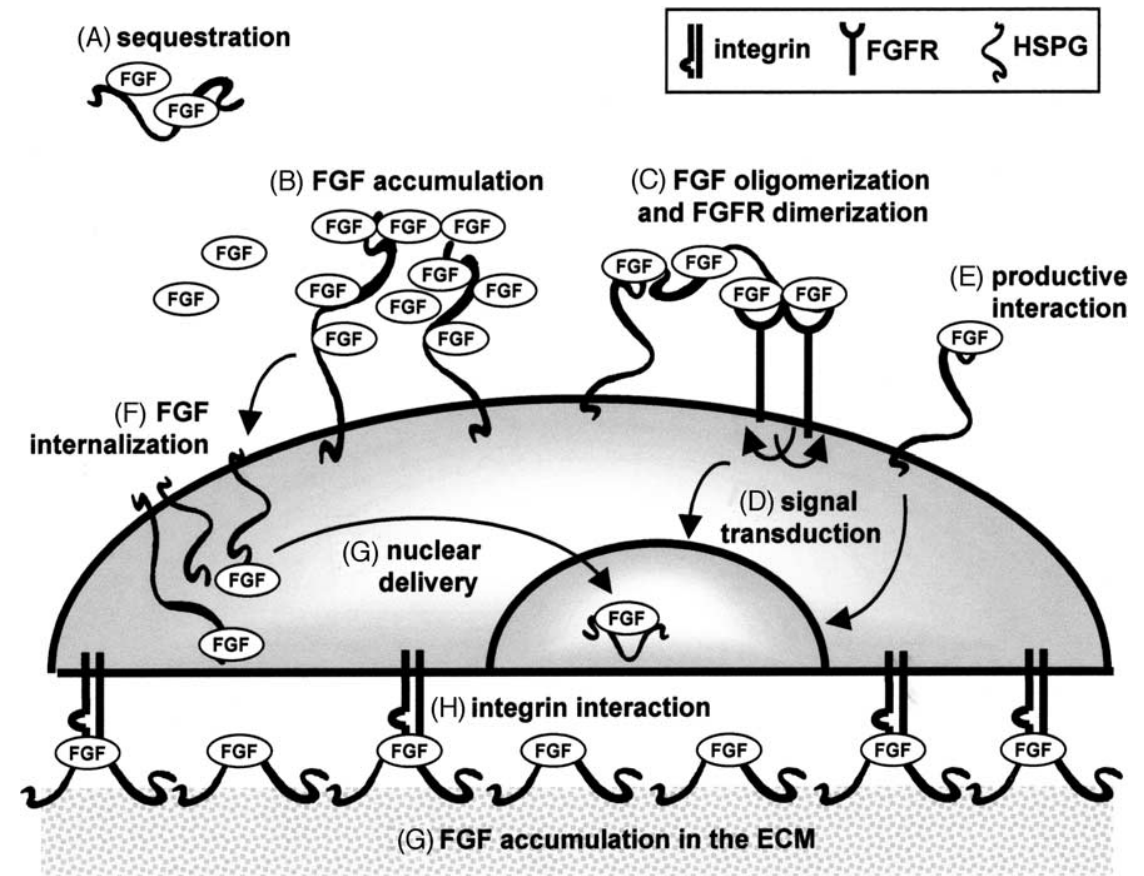

Fig. 3. Biological consequences of FGF/HSPG interaction. (A) FGF bound to free heparin/HSPGs is sequestered in the extracellular environment. (B) FGF binds to HSPGs of the endothelial cell surface, increasing its concentration in the microenvironment. (C) HSPGs promote FGF oligomerization that, in turn, triggers FGFRs dimerization and signal transduction (D) that can be activated also by a direct FGF/HSPG interaction (E). (F) HSPGs mediate cell internalization of FGF and, possibly, its nuclear delivery (G). (H) HSPGs of the ECM can present FGF to endothelial cell integrins to mediate substrate-adhesion.

HSPGs bound to fibronectin present FGF2 in a biologically active form [140]. Thus, HSPGs may facilitate the interaction of ECM components with FGF2 that, in turn, promotes endothelial cell adhesion and activation via $\alpha_{\mathrm{v}} \beta_{3}$ (Fig. 3).

Integrin $\alpha_{\mathrm{v}} \beta_{3}$ is expressed also at the luminal aspect of endothelium [141] suggesting that it may also mediate the biological affects exerted by free FGF2. Actually, anti- $\alpha_{\mathrm{v}} \beta_{3}$ antibodies [136] and RGD- or DGR-containing peptides [142] inhibit mitogenesis and protease upregulation triggered by free FGF2 in cultured endothelial cells. Accordingly, RGD-peptidomimetic inhibits FGF2-dependent neovascularization in the CAM assay and tumorigenesis in vivo [143].

\subsubsection{Gangliosides}

Gangliosides are neuraminic acid (NeuAc)-containing glycosphingolipids. Under physiological conditions, gangliosides are mainly associated to the membrane of different cell types, including endothelium, where they modulate cell growth, adhesion, and cell-cell interaction [144]. During tumor growth and metastatization, gangliosides shed in the microenvironment [145] with a consequent increase of their serum levels (Table 1) and accumulation in the tumor microenvironment. For instance, gangliosides are highly expressed in the hyper-vascularized areas of gliomas where they regulate angiogenesis [146].

Gangliosides bind FGF1, FGF2, and FGF4 via negatively charged Neu-Ac residues [147,148]. In the extracellular environment, gangliosides compete with free heparin for the binding to the growth factor. On endothelial cells, free gangliosides prevent the binding of FGF2 to FGFRs and HSPGs, thus inhibiting FGF2-mediated cell proliferation [147].

Ganglioside $\mathrm{GM}_{1}$ is expressed on the endothelial cell surface and binds FGF2 with an affinity that is significantly higher than that of its free counterpart (Table 1). Under these conditions, $\mathrm{GM}_{1}$ acts as a functional FGF2 co-receptor. Indeed, inhibitors of ganglioside synthesis or $\mathrm{GM}_{1}$-binding cholera toxin b-subunit impair the capacity of endothelial cells to proliferate when stimulated by FGF2. On the contrary, $\mathrm{GM}_{1}$ overloading of the cell membrane increases the responsiveness of endothelial cells to FGF2 [148].

\subsubsection{Thrombospondin-1}

Thrombospondin-1 (TSP-1) is a modular glycoprotein secreted by different cell types, including endothelial cells. It is composed of multiple active domains that bind to soluble factors, cell receptors, and ECM components [149]. In particular, TSP-1 associates to HSPGs of the ECM and binds integrin receptors [149]. TSP-1 was the first endogenous inhibitor of angiogenesis to be identified and its effect is due, at least in part, to its capacity to bind FGF2 [150]. The interaction is mediated by the COOH-terminal, anti-angiogenic $140 \mathrm{kDa}$ fragment of TSP-1. TSP-1 prevents the interaction of FGF2 with soluble heparin and with endothelial cell HSPGs and FGFRs. Accordingly, TSP-1 inhibits the mitogenic and chemotactic activity of FGF2 in endothelial cells. TSP-1 also prevents the accumulation of FGF2 in the ECM and favors the mobilization of matrix- 
bound FGF2, generating inactive TSP-1/FGF2 complexes [151]. These observations suggest that free TSP-1 can act as a scavenger for matrix-associated FGFs, affecting their location, bioavailability and function, whereas ECMassociated TSP-1 may act as a "FGF decoy", sequestering the growth factor in an inactive form.

\subsubsection{Fibstatin}

Fibstatin is a fibronectin fragment that binds FGF2 but not FGF1, FGF3, FGF6, or FGF12 [152]. Fibstatin inhibits FGF2-dependent proliferation, migration and tubulogenesis of endothelial cells in vitro and angiogenesis and tumor growth in vivo with high efficiency [152]. Like other FGFbinding partners (see above), fibstatin is endowed of the capacity to bind heparin and integrin receptors, suggesting that multiple interactions are responsible for the antiangiogenic activity of this molecule.

\subsubsection{FGF-binding protein}

FGF-binding protein (FGF-BP) is a secreted protein that binds FGF1 and FGF2 [153]. FGF-BP may act as a chaperone molecule that competes with HSPGs for growth factor binding and mobilizes FGFs from ECM, thus facilitating their interaction with FGFRs. FGF-BP can serve as an angiogenic switch for different tumor cell lines, including squamous cell carcinoma and colon cancer cells [154]. FGF-BP interacts also with the protein core of the proangiogenic, FGF2-binding HSPG perlecan [155].

\subsection{Serum components}

\subsubsection{Soluble FGFR1}

A soluble form of the extracellular portion of FGFR1 (xcFGFR1) is present in blood, in the cerebral spinal fluid, and in the vitreous fluid [see [156] and references therein]. Also, xcFGFR1 interacts with endothelial ECM [157]. xcFGFR1 binds FGF2 with an affinity that is lower than that of the intact receptor (Table 1), but sufficient to prevent FGF2/FGFR interaction when administered at high concentrations [158]. Also, xcFGFR1 may inhibit the biological activity of FGF1, FGF2, and FGF3 by forming heterodimers with cellular FGFR1, thus blocking the process of signal transduction [159]. Nevertheless, the impact of xcFGFR1 on angiogenesis remains to be investigated.

\subsubsection{Fibrinogen}

Fibrinogen is a $340 \mathrm{kDa}$ glycoprotein found in blood or immobilized on the blood vessel wall. Following blood vessel injury, fibrinogen is converted to fibrin that represents the temporary substrate for endothelial cell adhesion and migration in the initial phases of the healing process. Fibrin(ogen) binds FGF2, but not FGF1, with high affinity [118] without affecting FGF2/FGFR1 interaction. Indeed, FGF2 bound to immobilized fibrin(ogen) supports endothelial cell proliferation [118] and protease production [160]. The FGF2-potentiating effect of fibrin(ogen) requires $\alpha_{v} \beta_{3}$ that, in the presence of the adhesive protein, interacts with FGFR1 [138]. These observations, together with the capacity of fibrin(ogen) and FGF2 to bind $\alpha_{\mathrm{v}} \beta_{3}$, underlay the complex interplay among FGF, cell-surface receptors, ECM components, and diffusible molecules.

\subsection{3. $\alpha_{2}$-Macroglobulin}

$\alpha_{2}$-Macroglobulin $\left(\alpha_{2} M\right)$ is a $718 \mathrm{kDa}$ homotetrameric protein present in human plasma where it acts as a broadspecific proteinase inhibitor. To exert its activity, $\alpha_{2} \mathrm{M}$ undergoes major conformational changes that lead to the activated form $\alpha_{2} \mathrm{M}^{*}$. Both $\alpha_{2} \mathrm{M}$ and $\alpha_{2} \mathrm{M}^{*}$ bind a variety of cytokines and growth factors, including FGF1, FGF2, FGF4, and FGF6, but not FGF5, FGF7, FGF9, and FGF10 [161]. The binding of $\alpha_{2} \mathrm{M}$ to FGF2 occurs with high affinity (Table 1) and is primarily hydrophobic in nature [162]. $\alpha_{2} \mathrm{M}$ sequesters FGF2 in the extracellular environment and inhibits its cell interaction, protease-inducing activity [163] and mitogenic capacity [161]. Interestingly, both TGF- $\beta$ [162] and PDGF [163] compete with FGF2 for the binding to $\alpha_{2} \mathrm{M}$. Also, $\alpha_{2} \mathrm{M}$ competes with ECM components for FGF2 interaction [161].

\subsubsection{Pentraxin 3}

Pentraxin 3 (PTX3) is a $45 \mathrm{kDa}$ glycosylated protein predominantly assembled in 10-20 mer multimers [164]. Its $\mathrm{COOH}$-terminal domain shares homology with the classic short-pentraxin C-reactive protein whereas its $\mathrm{NH}_{2}$-terminal portion does not show significant homology with any other known protein [165]. PTX3 is synthesized and released by activated mononuclear phagocytes and endothelial cells [165] and acts as a soluble pattern recognition receptor with unique functions in various physiopathological conditions. These functions relay, at least in part, on the capacity of PTX3 to bind different structures (see [166] and references therein). PTX3 binds FGF2, but not FGF1 and FGF4, with high affinity [166]. In endothelial cells, PTX3 prevents the binding of FGF2 to cell surface FGFRs and HSPGs, with a consequent inhibition of cell proliferation and migration, and inhibits FGF2-dependent neovascularization in the CAM assay. Also, PTX3 overexpression in FGF2-transformed endothelial cells inhibits FGF2-dependent proliferation and invasion in vitro and tumorigenesis in vivo [166].

PTX3 exists both as a free or ECM-immobilized molecule [167]. Relevant to this point, FGF2 and PTX3 retains their binding capacity independently of their free or immobilized status [166]. Thus, as described for TSP-1, free PTX3 may have access to ECM-bound FGF2 by acting as a scavenger for the stored growth factor, whereas ECMassociated PTX3 may act as a "FGF2 decoy", sequestering the growth factor in an inactive form.

\subsection{Cytokines}

Platelet-derived growth factor BB (PDGF-BB) binds FGF2 in a 1:2 stoichiometry [168]. This interaction may 
contribute to the inhibitory effect exerted by PDGF-BB on FGF2-dependent neovascularization [169].

The heparin-binding C-X-C chemokine platelet factor 4 (PF4) is a well known inhibitor of angiogenesis ([170] and references therein). PF4 binds FGF1 [171] and FGF2 [170]. In endothelial cells, PF4 inhibits FGF2 interaction with HSPGs and FGFR1, FGF2 internalization and mitogenic activity [170]. Heparin stabilizes FGF2/PF4 interaction by forming a ternary complex [172]. On the other hand, PF4 binds and masks cell surface or ECM-associated HSPGs, hindering these receptors to FGF2 and FGF1 binding [173].

\section{FGF/FGFR system in tumor angiogenesis}

\subsection{Experimental tumors}

Various tumor cell lines express FGF2 [174,175] and the appearance of an angiogenic phenotype correlates with the export of FGF2 during the development of fibrosarcoma in a transgenic mouse model [176]. Antisense cDNAs for FGF2 and FGFR1 inhibit neovascularization and growth of human melanomas in nude mice [177]. Also, the anti-angiogenic activity of IFN- $\alpha / \beta$ appears to be related, at least in part, to the capacity to down-regulate FGF2 expression [178]. These data suggest that FGF2 production and release may occur in vivo and may influence the growth and neovascularization of tumor xenografts. Indeed, neutralizing anti-FGF2 antibodies and soluble FGFRs affect tumor growth under defined experimental conditions [179-182]. Accordingly, targeting FGF-BP with specific ribozymes inhibits the growth and vascularization of xenografted tumors in mice [154] despite the high levels of VEGF produced by these cells [183]. Interestingly, FGF-BP may exert its biological function via a paracrine stimulation on both tumor and endothelial cells [184]. Indeed, given the pleiotropic activity of FGFs, it is not always possible to dissociate the effect of FGFs on tumor angiogenesis from those exerted directly on tumor cells. For instance, S115 breast cancer cells transfected with FGF8b, but not with FGF8a or FGF8e, originate highly vascularized tumors when injected in nude mice. However, FGF8b also affect their ancorage-independent growth in vitro in an autocrine manner [17]. Similar results were reported for FGF4-transfected human breast carcinoma cells [185]. Also, inhibition of FGF/FGFR system in glioma cells by dominant negative FGFR transfection [99] or in prostate cancer cells by $f g f 2$ gene knockout [186] results in inhibition of tumor growth by both angiogenesis-dependent and -independent mechanisms.

Relevant to this point, constitutive $[187,188]$ or tetracycline-regulated [189] FGF2 overexpression causes a significant increase in the angiogenic activity and tumorigenic capacity of a VEGF-producing human endometrial adenocarcinoma cell line without affecting tumor cell proliferation in vitro [189]. These data suggest that modulation of FGF2 expression may indeed have a direct effect on angiogenesis and may allow a fine tuning of tumor vascularity even in the presence of VEGF (see above). Accordingly, simultaneous expression of FGF2 and VEGF in these tumor cells results in fast growing tumor xenografts in nude mice characterized by high blood vessel density, patency and permeability [106]. Inhibition of FGF2 production causes a significant decrease in the growth and vascularization of these lesions, without affecting vessel patency and permeability, pericyte recruitment, tumor necrosis, and oxygenation (as evaluated by HIF- $1 \alpha$ immunostaining). In contrast, the decrease in tumor growth and vascularization consequent to antisense VEGF cDNA transfection is also paralleled by a significant decrease in monocyte infiltrate, pericyte organization, vascular patency, and permeability. This results in an increase in HIF- $1 \alpha$ immunoreactivity and tumor necrosis. An additional inhibitory effect is exerted by FGF2 down-regulation in antisense VEGF cDNA transfected lesions. Thus, FGF2 and VEGF factors exert a synergistic effect on tumor blood vessel density in this model. However, FGF2 and VEGF differently affect blood vessel maturation and functionality (see also [112]).

In keeping with these observations, adenoviral expression of a soluble form of VEGFR-1 in spontaneous $\beta$-cell pancreatic tumors in Rip1 Tag2 mice affected the initial stages of tumor angiogenesis whereas soluble FGFR2 appeared to impair the maintenance of tumor angiogenesis. The combination of the two soluble receptors exerted a synergistic effect [182]. In addition, expression of a dominant-negative FGFR1 in the retina of Tryp1-Tag mice that develop early vascularized tumors of the retinal pigment epithelium results in a significant decrease in tumor burden and vascularity [190].

\subsection{Human tumors}

The possibility that FGFs may play a role in human tumor vascularization represents an important issue in FGF biology and for the development of anti-angiogenic therapies. Numerous studies have attempted to establish a correlation between intratumoral levels of FGF2 mRNA or protein and intratumoral microvessel density (MVD) in cancer patients. Table 2 summarizes the results from 53 independent studies that investigated the correlation between intratumoral FGF2 levels and MVD and between these two parameters and cancer progression/prognosis. Clearly, the bulk of data highlight a marked heterogeneity among different tumors and also among different studies within the same tumor type. With a few exceptions (e.g. melanomas) FGF2 levels do not correlate persistently with MVD. This is in sharp contrast with what observed for VEGF levels that more systemically correlate with MVD.

It is interesting to note that in some tumor types (e.g. breast and hepatocellular carcinomas) intratumoral levels of FGF2 correlate with the clinical outcome but not with MVD. As stated above, the pleiotropic activity of FGFs may affect 
Table 2

Correlation between intratumor FGF2 or VEGF levels with tumor vascularity (MVD) or clinical outcome

\begin{tabular}{|c|c|c|c|}
\hline Tumor type & FGF2 levels vs. MVD & FGF2 levels vs. clinical outcome ${ }^{a}$ & VEGF levels vs. MVD $^{b}$ \\
\hline Astrocytoma & +- & N.D. & ++ \\
\hline Basal cell carcinoma & - & - & + \\
\hline Bladder carcinoma & + & ++ & + \\
\hline Breast carcinoma & +---- & +++ & +++ \\
\hline Cardiac myxoma & + & N.D. & N.D. \\
\hline Colorectal adenocarcinoma & - & -- & +++ \\
\hline Epidermoid lung carcinoma & - & + & + \\
\hline Gastric carcinoma & - & - & + \\
\hline Glioma & ++- & +-- & ++ \\
\hline Hepatocellular carcinoma & - & ++ & + \\
\hline Laringeal adenocarcinoma & - & - & + \\
\hline Leiomyoma & - & N.D. & + \\
\hline Leiomyosarcoma & - & N.D. & + \\
\hline Melanoma & +++ & ++ & N.D. \\
\hline Meningioma & -- & --- & - \\
\hline Mesotelioma & + & + & + \\
\hline Non-Hodgkin's lymphoma & - & + & N.D. \\
\hline Non-small cell lung carcinoma & - & + & N.D. \\
\hline Pancreatic adenocarcinoma & ++- & ++- & +++ \\
\hline Parathyroid adenoma & + & - & N.D \\
\hline Pituitary adenoma & + & N.D. & + \\
\hline Prostatic adenocarcinoma & ++- & + & +++ \\
\hline Pulmonary adenocarcinoma & + & N.D. & + \\
\hline Renal carcinoma & -- & +- & - \\
\hline Squamous cell carcinoma & +++- & +--- & +++ \\
\hline Thymoma & - & - & N.D. \\
\hline
\end{tabular}

+: correlation; -: no correlation; N.D.: not determined. Multiple symbols refer to distinct studies on the same tumor type.

${ }^{a}$ Clinical features analysed in the various studies were: grading/staging, metastatic status, disease recurrence, poor prognosis.

b Only those studies in which VEGF was directly compared to FGF2 were included.

both tumor vasculature and tumor parenchyma. Thus, at variance with the more endothelial-specific VEGF, FGF2 (as well as other FGFs) may contribute to cancer progression not only by inducing neovascularization, but also by acting directly on tumor cells. Accordingly, the co-expression of FGF7/KGF and its receptor FGFR2 IIIb/KGFR correlates with the high proliferative activity and poor prognosis in lung adenocarcinoma [191].

Evaluation of MVD may have prognostic significance in solid tumors [192,193], lymphomas [194], and leukemia [195]. Quantification of the angiogenic proteins in body fluids may represent an indirect, non-invasive way to measure angiogenic activity in cancer patients. Serum concentration of angiogenic factors increases with tumor progression [196] and decreases in response to treatment and long-term disease control [197]. Thus, apart from providing prognostic information in early detection of primary tumors or to follow tumor progression, measurement of these circulating factors may be used to monitor tumor regression during therapy and for the selection of patients at high risk of recurrences after treatment [198].

Moreover, the prognostic significance of FGF levels in biological fluids of cancer patients is controversial. Early studies showed that elevated levels of FGF2 in urine samples collected from 950 patients having a wide variety of solid tumors, leukemia or lymphoma were significantly correlated with the status and the extent of disease [199]. However, no association between increased serum levels of FGF2 and tumor type was observed in later studies on a large spectrum of metastatic carcinomas even though two-thirds of the patients showing progressive disease had increasing serum levels of the angiogenic factor compared with less than onetenth of the patients showing response to therapy [200]. The clinical significance of circulating FGF2 in individual types of cancer has been recently reviewed [201]. Briefly, the levels of circulating FGF2 may have prognostic significance in head and neck cancer, lymphoma, leukemia, prostate carcinoma, and soft tissue sarcoma but they do not correlate with breast cancer progression and their significance in colorectal carcinoma is unclear. Also, after an encouraging report about a positive correlation between MVD and cerebrospinal fluid FGF2 in children with brain tumors [202], FGF2 levels in body fluids do not always reflect tumor vascularity. Moreover, serum FGF2 may not entirely derive from the neoplastic tissue in cancer patients [203].

In conclusion, clinical reports have not established yet a clear relationship among FGFs, tumor angiogenesis, and tumor progression/prognosis. Further studies assessing the correlation between FGF levels at the tumor site and/or in body fluids and MVD are eagerly awaited before these growth factors, as well as other angiogenic factors, can be used as prognostic indicators, surrogate markers of angiogenesis in cancer patients, and as targets for angiostatic therapies. 


\section{FGF-dependent angiogenesis and inflammation}

Inflammation is the response of a vascularized tissue to sub-lethal injury, designed to destroy or inactivate invading pathogens, remove waste and debris, and permit restoration of normal function, either through resolution or repair.

Inflammation may promote FGF-dependent angiogenesis (Fig. 4). Inflammatory cells, including mononuclear phagocytes [204,205], $\mathrm{CD}^{+}$and $\mathrm{CD}^{+} \mathrm{T}$ lymphocytes $[206,207]$, and mast cells [208] can express FGF2. Moreover, osmotic shock and shear stress induce the release of FGF2 from endothelial cells $[209,210]$. FGF2 production and release from endothelial cells are also triggered by IFN- $\alpha$ plus IL-2 [211], IL-1 $\beta$ [212], and nitric oxide (NO) [213]. NO is produced by vascular endothelium following stimulation by cytokines, bacterial endotoxins, inflammatory mediators, neuropeptides, and shear stress [214]. Even though FGF2-induced angiogenesis can occur independently of NO synthesis [215], the pro-angiogenic effects exerted by $\mathrm{NO}$ and NO-inducing molecules are due, at least in part, to the NO-mediated FGF2 upregulation in endothelial cells [216]. Thus, inflammatory mediators can activate the endothelium to synthesize and release FGFs that, in turn, will stimulate angiogenesis by an autocrine mechanism of action (Fig. 4). On the other hand, PTX3, synthesized locally by endothelial cells in response to IL- $1 \beta$ and TNF- $\alpha$, binds FGF2 and acts as a natural angiogenesis inhibitor (see above), thus allowing a fine tuning of FGF2 pro-angiogenic activity in inflammation.

The inflammatory response may also cause cell damage, fluid and plasma protein exudation, and hypoxia. Endothelial cell damage results in increased FGF2 production and release [217]; exudated fibrin(ogen) can bind FGF2 and enhances its biological activity (see above); hypoxia upregulates the production of angiogenic growth factor, including VEGF [218] and FGF2 [204]. Furthermore, hypoxia increases endothelial cell responsiveness to FGF2 by promoting HSPG synthesis [219] and upregulates FGF2 production also in vascular pericytes [220].

Conversely, by interacting with endothelial cells, FGF2 may amplify the inflammatory and angiogenic response by inducing vasoactive effects and the recruitment of an inflammatory infiltrate (Fig. 4). Indeed, FGF2, but not FGF1, causes vasodilation of coronary arterioles via an increase in NO production [221]. FGFs can also induce vascular permeability indirectly, by upregulating VEGF and proteases (see above), and directly, as suggested for FGF2 and FGF5 [222]. Transient exposure to FGF1 and FGF2

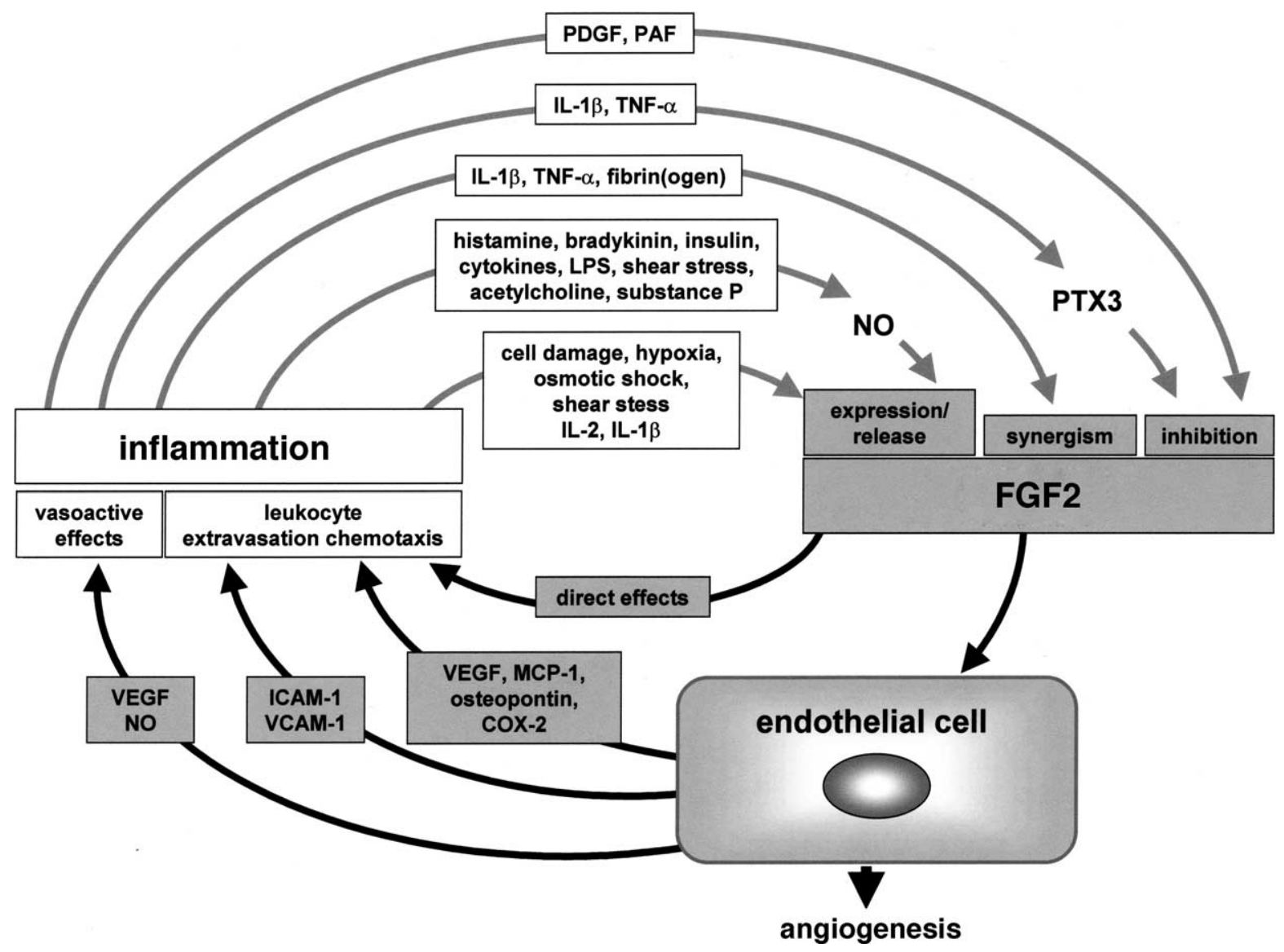

Fig. 4. Schematic representation of the interplay between FGFs and inflammation. Several inflammatory mediators can affect the biological activity of FGFs by different mechanisms. In turn, FGFs can modulate various steps of the inflammatory process by acting directly (or indirectly following endothelial cell activation) on inflammatory leukocytes. This results in the amplification of the angiogenic response triggered by FGFs on endothelial cells. 
upregulates the expression of cell adhesion molecules ICAM1 and VCAM-1 in endothelial cells, increasing polymorphonuclear leukocyte adhesion and transendothelial migration [223]. Also, FGF2-stimulated endothelial cells upregulate the synthesis of various chemoattractants, including VEGF, that may exert a chemotactic activity on monocytes [224], the angiogenic/monocyte chemotactic protein osteopontin [225], monocyte chemoattractant protein-1 [107,226], and the proangiogenic cyclooxygenase-2 [227]. Moreover, FGF2 exerts a direct chemotactic effect on monocytes (Presta, unpublished observations). Finally, in agreement with a possible role of inflammatory cells in FGF2-mediated neovascularization, a significant inhibition of the angiogenic response to FGF2 is observed in neutropenic mice [228].

Even though these experimental evidences point to a possible loop of amplification of the angiogenic response triggered by FGF2 and mediated by the inflammatory infiltrate, long-lasting exposure to FGF2 down-regulates cytokine-induced ICAM-1, VECAM-1, and E-selectin expression in endothelial cells. Consequently, polymorphonuclear leukocyte adhesion and transendothelial migration are reduced [223]. Similarly, monocyte/macrophages adhesion to endothelium and the chemotactic response to various chemokines are markedly inhibited by long-term stimulation by FGF1 or FGF2, but not by VEGF [229]. Also, FGF2 suppress transendothelial migration of $\mathrm{CD}^{+} \mathrm{T}$-lymphocytes [230] and tissue factor expression in endothelial cells [231]. These observations suggest that the pro- or anti-inflammatory activity of FGFs may be contextual and may explain, at least in part, the reduced leukocyte adhesion and transendothelial migration observed in experimental tumors [232] that, nevertheless, are characterized by the presence of proangiogenic tumor-associated macrophages [233].

\section{FGFs and therapeutic angiogenesis}

Therapeutic angiogenesis represents a possible approach to the treatment of severe ischemic diseases in patients with coronary (CAD) or peripheral (PAD) artery injury. Aim of this therapy is to restore and maintain tissue perfusion by increasing the number of collateral blood vessels within the ischemic territories following the delivery of specific angiogenic growth factors. Different delivery methods, including intravenous, intracoronary, intramyocardial and intrapericardial routes, are normally used to administer angiogenic factors either as recombinant proteins or by gene transfer using naked DNA or vectors that encode the gene to be incorporated into the target cells.

Among the different members of the FGF family, FGF1, FGF2, FGF4, and FGF5 have been more widely investigated, with particular emphasis to FGF2. For instance, in swine and canine models of coronary occlusion, intracoronary FGF2 administration or local injection in the myocardium can reduce scar size, preserve myocardial function, and increase number of blood vessels (reviewed in [234]).
In CAD patients, slow-release FGF2 capsules implanted in the myocardium in a phase I clinical trial caused a significant reduction in size of the ischemic region and treated patients had more freedom from angina recurrence than controls [235,236]. Also, single-bolus intracoronary FGF2 infusion showed transient beneficial effects, including reduction of angina symptoms, increase of treadmill tolerance and quality of life [237]. Transient beneficial effects were observed also in the phase II trial FIRST in which FGF2 was administered via intracoronary infusion [238]. In PAD patients, a positive response was observed in a phase I trial in which patients with symptoms of claudications and advanced peripheral arterial disease where given intra-arterial FGF2 infusion [239]. An early, transient improvement in performance was observed also in the phase II trial TRAFFIC in which patients with infrainguinal atherosclerosis and claudication received a bilateral intra-arterial infusion of FGF2 [240].

Experience with FGF1 is more limited. Early studies using a recombinant FGF1 protein reported no beneficial effects in a dog model of myocardial ischemia probably due to the short protein half-life. Indeed, administration of a FGF1 mutant with prolonged half-life showed an augmentation of blood flow and function in ischemic porcine myocardium [241]. Similar beneficial effects were observed in a hindlimb ischemia rabbit model using a single intramuscolar dose of naked DNA encoding FGF1 [242]. Phase I clinical trials have shown some beneficial effects following FGF1 protein injection in ischemic myocardium [243]. Similarly, intramuscular FGF1 gene injection in PAD patients resulted in a transient beneficial effect that was not sustained at 6 months [244].

The angiogenic potency of FGF4 and FGF5 was evaluated by gene therapy using an adenoviral vector in the rabbit hindlimb [94,245] and in the pig myocardium [246]. Adenovirus-delivered FGF4 was tested in two phase I clinical trials (AGENT and AGENT 2), involving patients with chronic stable angina. No beneficial effects were observed in both trials [246,247].

In conclusion, current clinical experience in ischemic disease suggest that FGF-based angiogenic therapy may represent a promising treatment for patients. However, further investigation is required to solve mayor problems that are critical to successful therapy: identification of the most effective delivery approach, proper selection of patients, timing and dosage of angiogenic factors used alone or in combinations [248].

\section{Acknowledgements}

Limitations of space preclude extensive citation of the literature; we apologize with those whose work is not mentioned herein. This work was supported by grants from AIRC, MIUR (Centro di Eccellenza "IDET", Firb 2001, Cofin 2002, and Cofin 2004), ISS (Oncotechnological 
Program), and Fondazione Berlucchi to MP and from MIUR (Cofin 2003) and ISS (AIDS Project) to MR.

\section{References}

[1] Carmeliet P, Jain RK. Angiogenesis in cancer and other diseases. Nature 2000;407:249-57.

[2] Hanahan D, Folkman J. Patterns and emerging mechanisms of the angiogenic switch during tumorigenesis. Cell 1996;86:353-64.

[3] Folkman J. Angiogenesis in cancer, vascular, rheumatoid and other disease. Nat Med 1995;1:27-31.

[4] Carmeliet P. Mechanisms of angiogenesis and arteriogenesis. Nat Med 2000;6:389-95.

[5] Folkman J, Merler E, Abernathy C, Williams G. Isolation of a tumor factor responsible or angiogenesis. J Exp Med 1971;133:275-88.

[6] Shing Y, Folkman J, Sullivan R, Butterfield C, Murray J, Klagsbrun M. Heparin affinity: purification of a tumor-derived capillary endothelial cell growth factor. Science 1984;223:1296-9.

[7] Maciag T, Mehlman T, Friesel R, Schreiber AB. Heparin binds endothelial cell growth factor, the principal endothelial cell mitogen in bovine brain. Science 1984;225:932-5.

[8] Itoh N, Ornitz DM. Evolution of the Fgf and Fgfr gene families. Trends Genet 2004;20:563-9.

[9] Bastaki M, Nelli EE, Dell'Era P, Rusnati M, Molinari-Tosatti MP, Parolini S, et al. Basic fibroblast growth factor-induced angiogenic phenotype in mouse endothelium. A study of aortic and microvascular endothelial cell lines. Arterioscler Thromb Vasc Biol 1997;17:454-64.

[10] Javerzat S, Auguste P, Bikfalvi A. The role of fibroblast growth factors in vascular development. Trends Mol Med 2002;8: 483-9.

[11] Dell'Era P, Belleri M, Stabile H, Massardi ML, Ribatti D, Presta M. Paracrine and autocrine effects of fibroblast growth factor- 4 in endothelial cells. Oncogene 2001;20:2655-63.

[12] Nachman RL, Jaffe EA. Endothelial cell culture: beginnings of modern vascular biology. J Clin Invest 1973;114:1037-40.

[13] Garlanda C, Dejana E. Heterogeneity of endothelial cells. Specific markers. Arterioscler Thromb Vasc Biol 1997;17:1193-202.

[14] McCarthy SA, Kuzu I, Gatter KC, Bicknell R. Heterogeneity of the endothelial cell and its role in organ preference of tumour metastasis. Trends Pharmacol Sci 1991;12:462-7.

[15] Chi JT, Chang HY, Haraldsen G, Jahnsen FL, Troyanskaya OG, Chang DS, et al. Endothelial cell diversity revealed by global expression profiling. Proc Natl Acad Sci USA 2003;100:10623-8.

[16] Cross MJ, Claesson-Welsh L. FGF and VEGF function in angiogenesis: signalling pathways, biological responses and therapeutic inhibition. Trends Pharmacol Sci 2001;22:201-7.

[17] Mattila MM, Ruohola JK, Valve EM, Tasanen MJ, Seppanen JA, Harkonen PL. FGF-8b increases angiogenic capacity and tumor growth of androgen-regulated S115 breast cancer cells. Oncogene 2001;20:2791-804.

[18] Presta M, Tiberio L, Rusnati M, Dell'Era P, Ragnotti G. Basic fibroblast growth factor requires a long-lasting activation of protein kinase $\mathrm{C}$ to induce cell proliferation in transformed fetal bovine aortic endothelial cells. Cell Regul 1991;2:719-26.

[19] Dell'Era P, Mohammadi M, Presta M. Different tyrosine autophosphorylation requirements in fibroblast growth factor receptor-1 mediate urokinase-type plasminogen activator induction and mitogenesis. Mol Biol Cell 1999;10:23-33.

[20] Liotta LA, Steeg PS, Stetler-Stevenson WG. Cancer metastasis and angiogenesis: an imbalance of positive and negative regulation. Cell 1991;64:327-36.

[21] Hiraoka N, Allen E, Apel IJ, Gyetko MR, Weiss SJ. Matrix metalloproteinases regulate neovascularization by acting as pericellular fibrinolysins. Cell 1998;95:365-77.
[22] Mignatti P, Rifkin DB. Nonenzymatic interactions between proteinases and the cell surface: novel roles in normal and malignant cell physiology. Adv Cancer Res 2000;78:103-57.

[23] Kaneko T, Fujii S, Matsumoto A, Goto D, Ishimori N, Watano K, et al. Induction of plasminogen activator inhibitor-1 in endothelial cells by basic fibroblast growth factor and its modulation by fibric acid. Arterioscler Thromb Vasc Biol 2002;22:855-60.

[24] Konkle BA, Kollros PR, Kelly MD. Heparin-binding growth factor-1 modulation of plasminogen activator inhibitor- 1 expression. Interaction with cAMP and protein kinase C-mediated pathways. J Biol Chem 1990;265:21867-73.

[25] Pepper MS, Sappino AP, Montesano R, Orci L, Vassalli JD. Plasminogen activator inhibitor-1 is induced in migrating endothelial cells. J Cell Physiol 1992;153:129-39.

[26] Taraboletti G, D'Ascenzo S, Borsotti P, Giavazzi R, Pavan A, Dolo V. Shedding of the matrix metalloproteinases MMP-2, MMP-9, and MT1-MMP as membrane vesicle-associated components by endothelial cells. Am J Pathol 2002;160:673-80.

[27] Terranova VP, DiFlorio R, Lyall RM, Hic S, Friesel R, Maciag T. Human endothelial cells are chemotactic to endothelial cell growth factor and heparin. J Cell Biol 1985;101:2330-4.

[28] Stokes CL, Rupnick MA, Williams SK, Lauffenburger DA. Chemotaxis of human microvessel endothelial cells in response to acidic fibroblast growth factor. Lab Invest 1990;63:657-68.

[29] Gillis P, Savla U, Volpert OV, Jimenez B, Waters CM, Panos RJ, et al. Keratinocyte growth factor induces angiogenesis and protects endothelial barrier function. J Cell Sci 1999;112(Pt 12):2049-57.

[30] Shono T, Kanetake H, Kanda S. The role of mitogen-activated protein kinase activation within focal adhesions in chemotaxis toward FGF-2 by murine brain capillary endothelial cells. Exp Cell Res 2001;264:275-83.

[31] Daviet I, Herbert JM, Maffrand JP. Involvement of protein kinase C in the mitogenic and chemotaxis effects of basic fibroblast growth factor on bovine cerebral cortex capillary endothelial cells. FEBS Lett 1990;259:315-7.

[32] Landgren E, Klint P, Yokote K, Claesson-Welsh L. Fibroblast growth factor receptor-1 mediates chemotaxis independently of direct SH2domain protein binding. Oncogene 1998;17:283-91.

[33] Kanda S, Lerner EC, Tsuda S, Shono T, Kanetake H, Smithgall TE. The nonreceptor protein-tyrosine kinase c-Fes is involved in fibroblast growth factor-2-induced chemotaxis of murine brain capillary endothelial cells. J Biol Chem 2000;275:10105-11.

[34] Shono T, Mochizuki Y, Kanetake H, Kanda S. Inhibition of FGF-2mediated chemotaxis of murine brain capillary endothelial cells by cyclic RGDfV peptide through blocking the redistribution of c-Src into focal adhesions. Exp Cell Res 2001;268:169-78.

[35] Nicosia RF, Ottinetti A. Modulation of microvascular growth and morphogenesis by reconstituted basement membrane gel in threedimensional cultures of rat aorta: a comparative study of angiogenesis in matrigel, collagen, fibrin, and plasma clot. In Vitro Cell Dev Biol 1990;26:119-28.

[36] Montesano R, Orci L, Vassalli P. In vitro rapid organization of endothelial cells into capillary-like networks is promoted by collagen matrices. J Cell Biol 1983;97:1648-52.

[37] Montesano R, Vassalli JD, Baird A, Guillemin R, Orci L. Basic fibroblast growth factor induces angiogenesis in vitro. Proc Natl Acad Sci USA 1986;83:7297-301.

[38] Matsumoto T, Turesson I, Book M, Gerwins P, Claesson-Welsh L. p38 MAP kinase negatively regulates endothelial cell survival, proliferation, and differentiation in FGF-2-stimulated angiogenesis. J Cell Biol 2002;156:149-60.

[39] Pepper MS, Belin D, Montesano R, Orci L, Vassalli JD. Transforming growth factor-beta 1 modulates basic fibroblast growth factorinduced proteolytic and angiogenic properties of endothelial cells in vitro. J Cell Biol 1990;111:743-55.

[40] Gajdusek CM, Luo Z, Mayberg MR. Basic fibroblast growth factor and transforming growth factor beta-1: synergistic mediators of angiogenesis in vitro. J Cell Physiol 1993;157:133-44. 
[41] Henke CA, Roongta U, Mickelson DJ, Knutson JR, McCarthy JB. CD44-related chondroitin sulfate proteoglycan, a cell surface receptor implicated with tumor cell invasion, mediates endothelial cell migration on fibrinogen and invasion into a fibrin matrix. J Clin Invest 1996;97:2541-52.

[42] Takei A, Tashiro Y, Nakashima Y, Sueishi K. Effects of fibrin on the angiogenesis in vitro of bovine endothelial cells in collagen gel. In Vitro Cell Dev Biol Anim 1995;31:467-72.

[43] Underwood PA, Bean PA, Gamble JR. Rate of endothelial expansion is controlled by cell:cell adhesion. Int $\mathrm{J}$ Biochem Cell Biol 2002;34:55-69.

[44] Hoying JB, Williams SK. Effects of basic fibroblast growth factor on human microvessel endothelial cell migration on collagen I correlates inversely with adhesion and is cell density dependent. J Cell Physiol 1996;168:294-304.

[45] Klein S, Giancotti FG, Presta M, Albelda SM, Buck CA, Rifkin DB. Basic fibroblast growth factor modulates integrin expression in microvascular endothelial cells. Mol Biol Cell 1993;4:973-82.

[46] Collo G, Pepper MS. Endothelial cell integrin alpha5beta1 expression is modulated by cytokines and during migration in vitro. J Cell Sci 1999;112(Pt 4):569-78.

[47] Sepp NT, Li LJ, Lee KH, Brown EJ, Caughman SW, Lawley TJ, et al. Basic fibroblast growth factor increases expression of the alpha $\mathrm{v}$ beta 3 integrin complex on human microvascular endothelial cells. J Invest Dermatol 1994;103:295-9.

[48] Zhou L, Dosanjh A, Chen H, Karasek M. Divergent effects of extracellular oxygen on the growth, morphology, and function of human skin microvascular endothelial cells. J Cell Physiol 2000;182:134-40.

[49] Gerritsen ME, Soriano R, Yang S, Zlot C, Ingle G, Toy K, et al. Branching out: a molecular fingerprint of endothelial differentiation into tube-like structures generated by Affymetrix oligonucleotide arrays. Microcirculation 2003;10:63-81.

[50] Kumar R, Yoneda J, Bucana CD, Fidler IJ. Regulation of distinct steps of angiogenesis by different angiogenic molecules. Int J Oncol 1998;12:749-57.

[51] Schnaper HW, Grant DS, Stetler-Stevenson WG, Fridman R, D’Orazi G, Murphy AN, et al. Type IV collagenase(s) and TIMPs modulate endothelial cell morphogenesis in vitro. J Cell Physiol 1993;156:235-46.

[52] Schnaper HW, Barnathan ES, Mazar A, Maheshwari S, Ellis S, Cortez SL, et al. Plasminogen activators augment endothelial cell organization in vitro by two distinct pathways. J Cell Physiol 1995;165:107-18.

[53] Davis GE, Camarillo CW. Regulation of endothelial cell morphogenesis by integrins, mechanical forces, and matrix guidance pathways. Exp Cell Res 1995;216:113-23.

[54] Sheibani N, Newman PJ, Frazier WA. Thrombospondin-1, a natural inhibitor of angiogenesis, regulates platelet-endothelial cell adhesion molecule-1 expression and endothelial cell morphogenesis. Mol Biol Cell 1997;8:1329-41.

[55] Connolly JO, Simpson N, Hewlett L, Hall A. Rac regulates endothelial morphogenesis and capillary assembly. Mol Biol Cell 2002;13:2474-85.

[56] Kanda S, Miyata Y, Kanetake H. Fibroblast growth factor-2-mediated capillary morphogenesis of endothelial cells requires signals via Flt1/vascular endothelial growth factor receptor-1: possible involvement of c-Akt. J Biol Chem 2004;279:4007-16.

[57] Gualandris A, Rusnati M, Belleri M, Nelli EE, Bastaki M, MolinariTosatti MP, et al. Basic fibroblast growth factor overexpression in endothelial cells: an autocrine mechanism for angiogenesis and angioproliferative diseases. Cell Growth Differ 1996;7:147-60.

[58] Ensoli B, Gendelman R, Markham P, Fiorelli V, Colombini S, Raffeld $\mathrm{M}$, et al. Synergy between basic fibroblast growth factor and HIV-1 Tat protein in induction of Kaposi's sarcoma. Nature 1994;371:674-80.

[59] Takahashi K, Mulliken JB, Kozakewich HP, Rogers RA, Folkman J, Ezekowitz RA. Cellular markers that distinguish the phases of hemangioma during infancy and childhood. J Clin Invest 1994;93:2357-64.

[60] Kiuru-Kuhlefelt S, Sarlomo-Rikala M, Larramendy ML, Soderlund M, Hedman K, Miettinen M, et al. FGF4 and INT2 oncogenes are amplified and expressed in Kaposi's sarcoma. Mod Pathol 2000;13: 433-7.

[61] Ribatti D, Gualandris A, Belleri M, Massardi L, Nico B, Rusnati M, et al. Alterations of blood vessel development by endothelial cells overexpressing fibroblast growth factor-2. J Pathol 1999;189: 590-9.

[62] Dell'Era P, Coco L, Ronca R, Sennino B, Presta M. Gene expression profile in fibroblast growth factor 2-transformed endothelial cells. Oncogene 2002;21:2433-40.

[63] Gualandris A, Urbinati C, Rusnati M, Ziche M, Presta M. Interaction of high-molecular-weight basic fibroblast growth factor with endothelium: biological activity and intracellular fate of human recombinant M(r) 24,000 bFGF. J Cell Physiol 1994;161:149-59.

[64] Mignatti P, Morimoto T, Rifkin DB. Basic fibroblast growth factor, a protein devoid of secretory signal sequence, is released by cells via a pathway independent of the endoplasmic reticulum-Golgi complex. J Cell Physiol 1992;151:81-93.

[65] Taverna S, Ghersi G, Ginestra A, Rigogliuso S, Pecorella S, Alaimo $\mathrm{G}$, et al. Shedding of membrane vesicles mediates fibroblast growth factor-2 release from cells. J Biol Chem 2003;278:51911-9.

[66] Bikfalvi A, Klein S, Pintucci G, Quarto N, Mignatti P, Rifkin DB. Differential modulation of cell phenotype by different molecular weight forms of basic fibroblast growth factor: possible intracellular signaling by the high molecular weight forms. J Cell Biol 1995;129:233-43.

[67] Florkiewicz RZ, Baird A, Gonzalez AM. Multiple forms of bFGF: differential nuclear and cell surface localization. Growth Factors 1991;4:265-75.

[68] Quarto N, Talarico D, Florkiewicz R, Rifkin DB. Selective expression of high molecular weight basic fibroblast growth factor confers a unique phenotype to NIH 3T3 cells. Cell Regul 1991;2:699-708.

[69] Talarico D, Basilico C. The K-fgf/hst oncogene induces transformation through an autocrine mechanism that requires extracellular stimulation of the mitogenic pathway. Mol Cell Biol 1991;11:1138-45.

[70] Partridge CR, Hawker Jr JR, Forough R. Overexpression of a secretory form of FGF-1 promotes MMP-1-mediated endothelial cell migration. J Cell Biochem 2000;78:487-99.

[71] Gonzalez AM, Hill DJ, Logan A, Maher PA, Baird A. Distribution of fibroblast growth factor (FGF)-2 and FGF receptor-1 messenger RNA expression and protein presence in the mid-trimester human fetus. Pediatr Res 1996;39:375-85.

[72] Arany E, Hill DJ. Fibroblast growth factor-2 and fibroblast growth factor receptor-1 mRNA expression and peptide localization in placentae from normal and diabetic pregnancies. Placenta 1998;19:133-42.

[73] Yoon SY, Tefferi A, Li CY. Cellular distribution of platelet-derived growth factor, transforming growth factor-beta, basic fibroblast growth factor, and their receptors in normal bone marrow. Acta Haematol 2000;104:151-7.

[74] Yamaguchi TP, Harpal K, Henkemeyer M, Rossant J. fgfr-1 is required for embryonic growth and mesodermal patterning during mouse gastrulation. Genes Dev 1994;8:3032-44.

[75] Deng CX, Wynshaw-Boris A, Shen MM, Daugherty C, Ornitz DM, Leder P. Murine FGFR-1 is required for early postimplantation growth and axial organization. Genes Dev 1994;8:3045-57.

[76] Lee SH, Schloss DJ, Swain JL. Maintenance of vascular integrity in the embryo requires signaling through the fibroblast growth factor receptor. J Biol Chem 2000;275:33679-87.

[77] Xu X, Weinstein M, Li C, Naski M, Cohen RI, Ornitz DM, et al. Fibroblast growth factor receptor 2 (FGFR2)-mediated reciprocal regulation loop between FGF8 and FGF10 is essential for limb induction. Development 1998;125:753-65. 
[78] Colvin JS, Bohne BA, Harding GW, McEwen DG, Ornitz DM. Skeletal overgrowth and deafness in mice lacking fibroblast growth factor receptor 3. Nat Genet 1996;12:390-7.

[79] Weinstein M, Xu X, Ohyama K, Deng CX. FGFR-3 FGFR-4 function cooperatively to direct alveogenesis in the murine lung. Development 1998;125:3615-23.

[80] Ribatti D, Vacca A, Roncali L, Dammacco F. The chick embryo chorioallantoic membrane as a model for in vivo research on antiangiogenesis. Curr Pharm Biotechnol 2000;1:73-82.

[81] Herbert JM, Laplace MC, Maffrand JP. Effect of heparin on the angiogenic potency of basic and acidic fibroblast growth factors in the rabbit cornea assay. Int J Tissue React 1988;10:133-9.

[82] Seghezzi G, Patel S, Ren CJ, Gualandris A, Pintucci G, Robbins ES, et al. Fibroblast growth factor-2 (FGF-2) induces vascular endothelial growth factor (VEGF) expression in the endothelial cells of forming capillaries: an autocrine mechanism contributing to angiogenesis. J Cell Biol 1998;141:1659-73.

[83] Passaniti A, Taylor RM, Pili R, Guo Y, Long PV, Haney JA, et al. A simple, quantitative method for assessing angiogenesis and antiangiogenic agents using reconstituted basement membrane, heparin, and fibroblast growth factor. Lab Invest 1992;67:519-28.

[84] Ribatti D, Nico B, Morbidelli L, Donnini S, Ziche M, Vacca A, et al. Cell-mediated delivery of fibroblast growth factor-2 and vascular endothelial growth factor onto the chick chorioallantoic membrane: endothelial fenestration and angiogenesis. J Vasc Res 2001;38:38997.

[85] Ribatti D, Presta M. The role of fibroblast growth factor-2 in the vascularization of the chick embryo chorioallantoic membrane. J Cell Mol Med 2002;6:439-46.

[86] Parsons-Wingerter P, Elliott KE, Clark JI, Farr AG. Fibroblast growth factor-2 selectively stimulates angiogenesis of small vessels in arterial tree. Arterioscler Thromb Vasc Biol 2000;20:1250-6.

[87] Zhou M, Sutliff RL, Paul RJ, Lorenz JN, Hoying JB, Haudenschild $\mathrm{CC}$, et al. Fibroblast growth factor 2 control of vascular tone. Nat Med 1998;4:201-7.

[88] Tobe T, Ortega S, Luna JD, Ozaki H, Okamoto N, Derevjanik NL, et al. Targeted disruption of the FGF2 gene does not prevent choroidal neovascularization in a murine model. Am J Pathol 1998;153:16416.

[89] Ozaki H, Okamoto N, Ortega S, Chang M, Ozaki K, Sadda S, et al. Basic fibroblast growth factor is neither necessary nor sufficient for the development of retinal neovascularization. Am J Pathol 1998;153:757-65.

[90] Fulgham DL, Widhalm SR, Martin S, Coffin JD. FGF-2 dependent angiogenesis is a latent phenotype in basic fibroblast growth factor transgenic mice. Endothelium 1999;6:185-95.

[91] Miller DL, Ortega S, Bashayan O, Basch R, Basilico C. Compensation by fibroblast growth factor 1 (FGF1) does not account for the mild phenotypic defects observed in FGF2 null mice. Mol Cell Biol 2000;20:2260-8.

[92] Costa M, Danesi R, Agen C, Di Paolo A, Basolo F, Del Bianchi S, et al. MCF-10A cells infected with the int- 2 oncogene induce angiogenesis in the chick chorioallantoic membrane and in the rat mesentery. Cancer Res 1994;54:9-11.

[93] Brustle O, Aguzzi A, Talarico D, Basilico C, Kleihues P, Wiestler OD. Angiogenic activity of the K-fgf/hst oncogene in neural transplants. Oncogene 1992;7:1177-83.

[94] Rissanen TT, Markkanen JE, Arve K, Rutanen J, Kettunen MI, Vajanto I, et al. Fibroblast growth factor 4 induces vascular permeability, angiogenesis and arteriogenesis in a rabbit hindlimb ischemia model. FASEB J 2003;17:100-2.

[95] Giordano FJ, Ping P, McKirnan MD, Nozaki S, DeMaria AN, Dillmann WH, et al. Intracoronary gene transfer of fibroblast growth factor-5 increases blood flow and contractile function in an ischemic region of the heart. Nat Med 1996;2:534-9.

[96] Zhao S, Overbeek PA. Regulation of choroid development by the retinal pigment epithelium. Mol Vis 2001;7:277-82.
[97] Ferrara N, Gerber HP, LeCouter J. The biology of VEGF and its receptors. Nat Med 2003;9:669-76.

[98] Tille JC, Wood J, Mandriota SJ, Schnell C, Ferrari S, Mestan J, et al. Vascular endothelial growth factor (VEGF) receptor-2 antagonists inhibit VEGF- and basic fibroblast growth factor-induced angiogenesis in vivo and in vitro. J Pharmacol Exp Ther 2001;299:1073-85.

[99] Auguste P, Gursel DB, Lemiere S, Reimers D, Cuevas P, Carceller F, et al. Inhibition of fibroblast growth factor/fibroblast growth factor receptor activity in glioma cells impedes tumor growth by both angiogenesis-dependent and -independent mechanisms. Cancer Res 2001;61:1717-26.

[100] Gabler C, Plath-Gabler A, Killian GJ, Berisha B, Schams D. Expression pattern of fibroblast growth factor (FGF) and vascular endothelial growth factor (VEGF) system members in bovine corpus luteum endothelial cells during treatment with FGF-2, VEGF or oestradiol. Reprod Domest Anim 2004;39:321-7.

[101] Tomanek RJ, Sandra A, Zheng W, Brock T, Bjercke RJ, Holifield JS. Vascular endothelial growth factor and basic fibroblast growth factor differentially modulate early postnatal coronary angiogenesis. Circ Res 2001;88:1135-41.

[102] Xue L, Greisler HP. Angiogenic effect of fibroblast growth factor-1 and vascular endothelial growth factor and their synergism in a novel in vitro quantitative fibrin-based 3-dimensional angiogenesis system. Surgery 2002;132:259-67.

[103] Castellon R, Hamdi HK, Sacerio I, Aoki AM, Kenney MC, Ljubimov AV. Effects of angiogenic growth factor combinations on retinal endothelial cells. Exp Eye Res 2002;74:523-35.

[104] Pepper MS, Mandriota SJ. Regulation of vascular endothelial growth factor receptor-2 (Flk-1) expression in vascular endothelial cells. Exp Cell Res 1998;241:414-25.

[105] Nico B, de Falco G, Vacca A, Roncali L, Ribatti D. In vivo absence of synergism between fibroblast growth factor- 2 and vascular endothelial growth factor. J Hematother Stem Cell Res 2001;10:905-12.

[106] Giavazzi R, Sennino B, Coltrini D, Garofalo A, Dossi R, Ronca R, et al. Distinct role of fibroblast growth factor- 2 and vascular endothelial growth factor on tumor growth and angiogenesis. Am J Pathol 2003;162:1913-26.

[107] Jih YJ, Lien WH, Tsai WC, Yang GW, Li C, Wu LW. Distinct regulation of genes by bFGF and VEGF-A in endothelial cells. Angiogenesis 2001;4:313-21.

[108] Ho M, Yang E, Matcuk G, Deng D, Sampas N, Tsalenko A, et al. Identification of endothelial cell genes by combined database mining and microarray analysis. Physiol Genomics 2003;13:249-62.

[109] Kurz DJ, Hong Y, Trivier E, Huang HL, Decary S, Zang GH, et al. Fibroblast growth factor-2, but not vascular endothelial growth factor, upregulates telomerase activity in human endothelial cells. Arterioscler Thromb Vasc Biol 2003;23:748-54.

[110] Chang L, Kaipainen A, Folkman J. Lymphangiogenesis new mechanisms. Ann N Y Acad Sci 2002;979:111-9.

[111] Chang LK, Garcia-Cardena G, Farnebo F, Fannon M, Chen EJ, Butterfield C, et al. Dose-dependent response of FGF-2 for lymphangiogenesis. Proc Natl Acad Sci USA 2004;101:11658-63.

[112] Cao R, Eriksson A, Kubo H, Alitalo K, Cao Y, Thyberg J. Comparative evaluation of FGF-2-, VEGF-A-, and VEGF-C-induced angiogenesis, lymphangiogenesis, vascular fenestrations, and permeability. Circ Res 2004;94:664-70.

[113] Carmeliet P. Mechanisms of angiogenesis and arteriogenesis. Nat Med 2000;6:389-95.

[114] Poole TJ, Finkelstein EB, Cox CM. The role of FGF and VEGF in angioblast induction and migration during vascular development. Dev Dyn 2001;220:1-17.

[115] Desbaillets I, Ziegler U, Groscurth P, Gassmann M. Embryoid bodies: an in vitro model of mouse embryogenesis. Exp Physiol 2000;85:645-51.

[116] Kazemi S, Wenzel D, Kolossov E, Lenka N, Raible A, Sasse P, et al. Differential role of bFGF and VEGF for vasculogenesis. Cell Physiol Biochem 2002;12:55-62. 
[117] Magnusson P, Rolny C, Jakobsson L, Wikner C, Wu Y, Hicklin DJ, et al. Deregulation of Flk-1/vascular endothelial growth factor receptor2 in fibroblast growth factor receptor-1-deficient vascular stem cell development. J Cell Sci 2004;117:1513-23.

[118] Sahni A, Altland OD, Francis CW. FGF-2 but not FGF-1 binds fibrin and supports prolonged endothelial cell growth. J Thromb Haemost 2003;1:1304-10.

[119] Lindahl U, Lidholt K, Spillmann D, Kjellen L. More to "heparin" than anticoagulation. Thromb Res 1994;75:1-32.

[120] Iozzo RV, San Antonio JD. Heparan sulfate proteoglycans: heavy hitters in the angiogenesis arena. J Clin Invest 2001;108:349-55.

[121] Rusnati M, Presta M. Interaction of angiogenic basic fibroblast growth factor with endothelial cell heparan sulfate proteoglycans. Biological implications in neovascularization. Int J Clin Lab Res 1996;26:15-23.

[122] Pellegrini L. Role of heparan sulfate in fibroblast growth factor signalling: a structural view. Curr Opin Struct Biol 2001;11:629-34.

[123] Eriksson AE, Cousens LS, Weaver LH, Matthews BW. Three-dimensional structure of human basic fibroblast growth factor. Proc Natl Acad Sci USA 1991;88:3441-5.

[124] Simons M, Horowitz A. Syndecan-4-mediated signalling. Cell Signal 2001;13:855-62.

[125] Rusnati M, Urbinati C, Presta M. Internalization of basic fibroblast growth factor (bFGF) in cultured endothelial cells: role of the low affinity heparin-like bFGF receptors. J Cell Physiol 1993;154:15261.

[126] Hsia E, Richardson TP, Nugent MA. Nuclear localization of basic fibroblast growth factor is mediated by heparan sulfate proteoglycans through protein kinase C signaling. J Cell Biochem 2003;88:121425.

[127] Presta M, Maier JA, Rusnati M, Ragnotti G. Basic fibroblast growth factor is released from endothelial extracellular matrix in a biologically active form. J Cell Physiol 1989;140:68-74.

[128] Presta M, Leali D, Stabile H, Ronca R, Camozzi M, Coco L, et al. Heparin derivatives as angiogenesis inhibitors. Curr Pharm Des 2003;9:553-66.

[129] Nurcombe V, Ford MD, Wildschut JA, Bartlett PF. Developmental regulation of neural response to FGF-1 and FGF-2 by heparan sulfate proteoglycan. Science 1993;260:103-6.

[130] Jaakkola P, Jalkanen M. Transcriptional regulation of Syndecan-1 expression by growth factors. Prog Nucleic Acid Res Mol Biol 1999;63:109-38.

[131] Vlodavsky I, Korner G, Ishai-Michaeli R, Bashkin P, Bar-Shavit R, Fuks Z. Extracellular matrix-resident growth factors and enzymes: possible involvement in tumor metastasis and angiogenesis. Cancer Metastasis Rev 1990;9:203-26.

[132] Ribatti D, Leali D, Vacca A, Giuliani R, Gualandris A, Roncali L, et al. In vivo angiogenic activity of urokinase: role of endogenous fibroblast growth factor-2. J Cell Sci 1999;112(Pt 23):4213-21.

[133] Ruegg C, Mariotti A. Vascular integrins: pleiotropic adhesion and signaling molecules in vascular homeostasis and angiogenesis. Cell Mol Life Sci 2003;60:1135-57.

[134] Eliceiri BP. Integrin and growth factor receptor crosstalk. Circ Res 2001;89:1104-10.

[135] Kumar CC. Integrin alpha v beta 3 as a therapeutic target for blocking tumor-induced angiogenesis. Curr Drug Targets 2003;4:123-31.

[136] Rusnati M, Tanghetti E, Dell'Era P, Gualandris A, Presta M. alphavbeta 3 integrin mediates the cell-adhesive capacity and biological activity of basic fibroblast growth factor (FGF-2) in cultured endothelial cells. Mol Biol Cell 1997;8:2449-61.

[137] Tanghetti E, Ria R, Dell'Era P, Urbinati C, Rusnati M, Ennas MG, et al. Biological activity of substrate-bound basic fibroblast growth factor (FGF2): recruitment of FGF receptor-1 in endothelial cell adhesion contacts. Oncogene 2002;21:3889-97.

[138] Sahni A, Francis CW. Stimulation of endothelial cell proliferation by FGF-2 in the presence of fibrinogen requires $\{$ alpha $\}$ v $\{$ beta $\}$. Blood 2004;104:3635-41.
[139] Presta M, Oreste P, Zoppetti G, Belleri M, Tanghetti E, Leali D, et al. Antiangiogenic activity of semisynthetic biotechnological heparins: low-molecular-weight-sulfated Escherichia coli K5 polysaccharide derivatives as fibroblast growth factor antagonists. Arterioscler Thromb Vasc Biol 2005;25:71-6.

[140] Salmivirta M, Heino J, Jalkanen M. Basic fibroblast growth factorsyndecan complex at cell surface or immobilized to matrix promotes cell growth. J Biol Chem 1992;267:17606-10.

[141] Conforti G, Dominguez-Jimenez C, Zanetti A, Gimbrone Jr MA, Cremona O, Marchisio PC, et al. Human endothelial cells express integrin receptors on the luminal aspect of their membrane. Blood 1992;80:437-46.

[142] Presta M, Rusnati M, Urbinati C, Sommer A, Ragnotti G. Biologically active synthetic fragments of human basic fibroblast growth factor (bFGF): identification of two Asp-Gly-Arg-containing domains involved in the mitogenic activity of bFGF in endothelial cells. J Cell Physiol 1991;149:512-24.

[143] Kumar CC, Malkowski M, Yin Z, Tanghetti E, Yaremko B, Nechuta $\mathrm{T}$, et al. Inhibition of angiogenesis and tumor growth by $\mathrm{SCH} 221153$, a dual alpha(v)beta3 and alpha(v)beta5 integrin receptor antagonist. Cancer Res 2001;61:2232-8.

[144] Birkle S, Zeng G, Gao L, Yu RK, Aubry J. Role of tumor-associated gangliosides in cancer progression. Biochimie 2003;85:455-63.

[145] Chang F, Li R, Ladisch S. Shedding of gangliosides by human medulloblastoma cells. Exp Cell Res 1997;234:341-6.

[146] Koochekpour S, Merzak A, Pilkington GJ. Vascular endothelial growth factor production is stimulated by gangliosides and TGFbeta isoforms in human glioma cells in vitro. Cancer Lett 1996;102:209-15.

[147] Rusnati M, Tanghetti E, Urbinati C, Tulipano G, Marchesini S, Ziche $\mathrm{M}$, et al. Interaction of fibroblast growth factor-2 (FGF-2) with free gangliosides: biochemical characterization and biological consequences in endothelial cell cultures. Mol Biol Cell 1999;10: 313-27.

[148] Rusnati M, Urbinati C, Tanghetti E, Dell'Era P, Lortat-Jacob H, Presta M. Cell membrane GM1 ganglioside is a functional coreceptor for fibroblast growth factor 2. Proc Natl Acad Sci USA 2002;99:4367-72.

[149] Bornstein P, Armstrong LC, Hankenson KD, Kyriakides TR, Yang Z. Thrombospondin 2, a matricellular protein with diverse functions. Matrix Biol 2000;19:557-68.

[150] Taraboletti G, Belotti D, Borsotti P, Vergani V, Rusnati M, Presta M, et al. The 140-kilodalton antiangiogenic fragment of thrombospondin-1 binds to basic fibroblast growth factor. Cell Growth Differ 1997;8:471-9.

[151] Margosio B, Marchetti D, Vergani V, Giavazzi R, Rusnati M, Presta $\mathrm{M}$, et al. Thrombospondin 1 as a scavenger for matrix-associated fibroblast growth factor 2. Blood 2003;102:4399-406.

[152] Bossard C, Van den Berghe L, Laurell H, Castano C, Cerutti M, Prats $\mathrm{AC}$, et al. Antiangiogenic properties of fibstatin, an extracellular FGF-2-binding polypeptide. Cancer Res 2004;64:7507-12.

[153] Tassi E, Al-Attar A, Aigner A, Swift MR, McDonnell K, Karavanov A, et al. Enhancement of fibroblast growth factor (FGF) activity by an FGF-binding protein. J Biol Chem 2001;276:40247-53.

[154] Czubayko F, Liaudet-Coopman ED, Aigner A, Tuveson AT, Berchem GJ, Wellstein A. A secreted FGF-binding protein can serve as the angiogenic switch in human cancer. Nat Med 1997;3:1137-40.

[155] Mongiat M, Otto J, Oldershaw R, Ferrer F, Sato JD, Iozzo RV. Fibroblast growth factor-binding protein is a novel partner for perlecan protein core. J Biol Chem 2001;276:10263-71.

[156] Hanneken A, Baird A. Soluble forms of the high-affinity fibroblast growth factor receptor in human vitreous fluid. Invest Ophthalmol Vis Sci 1995;36:1192-6.

[157] Hanneken A, Maher PA, Baird A. High affinity immunoreactive FGF receptors in the extracellular matrix of vascular endothelial cellsimplications for the modulation of FGF-2. J Cell Biol 1995;128: 1221-8. 
[158] Bergonzoni L, Caccia P, Cletini O, Sarmientos P, Isacchi A. Characterization of a biologically active extracellular domain of fibroblast growth factor receptor 1 expressed in Escherichia coli. Eur J Biochem 1992;210:823-9.

[159] Ueno H, Gunn M, Dell K, Tseng Jr A, Williams L. A truncated form of fibroblast growth factor receptor 1 inhibits signal transduction by multiple types of fibroblast growth factor receptor. J Biol Chem 1992;267:1470-6.

[160] Sahni A, Sahni SK, Simpson-Haidaris PJ, Francis CW. Fibrinogen binding potentiates FGF-2 but not VEGF induced expression of $\mathrm{u}$ PA, u-PAR, and PAI-1 in endothelial cells. J Thromb Haemost 2004;2:1629-36.

[161] Asplin IR, Wu SM, Mathew S, Bhattacharjee G, Pizzo SV. Differential regulation of the fibroblast growth factor (FGF) family by alpha(2)-macroglobulin: evidence for selective modulation of FGF2-induced angiogenesis. Blood 2001;97:3450-7.

[162] Mathew S, Arandjelovic S, Beyer WF, Gonias SL, Pizzo SV. Characterization of the interaction between alpha2-macroglobulin and fibroblast growth factor-2: the role of hydrophobic interactions. Biochem J 2003;374:123-9.

[163] Dennis PA, Saksela O, Harpel P, Rifkin DB. Alpha 2-macroglobulin is a binding protein for basic fibroblast growth factor. J Biol Chem 1989;264:7210-6.

[164] Bottazzi B, Vouret-Craviari V, Bastone A, De Gioia L, Matteucci C, Peri G, et al. Multimer formation and ligand recognition by the long pentraxin PTX3. Similarities and differences with the short pentraxins C-reactive protein and serum amyloid $\mathrm{P}$ component. J Biol Chem 1997;272:32817-23.

[165] Breviario F, d'Aniello EM, Golay J, Peri G, Bottazzi B, Bairoch A, et al. Interleukin-1-inducible genes in endothelial cells. Cloning of a new gene related to $\mathrm{C}$-reactive protein and serum amyloid $\mathrm{P}$ component. J Biol Chem 1992;267:22190-7.

[166] Rusnati M, Camozzi M, Moroni E, Bottazzi B, Peri G, Indraccolo S, et al. Selective recognition of fibroblast growth factor- 2 by the long pentraxin PTX3 inhibits angiogenesis. Blood 2004;104:92-9.

[167] Salustri A, Garlanda C, Hirsch E, De Acetis M, Maccagno A, Bottazzi B, et al. PTX3 plays a key role in the organization of the cumulus oophorus extracellular matrix and in in vivo fertilization. Development 2004;131:1577-86.

[168] Russo K, Ragone R, Facchiano AM, Capogrossi MC, Facchiano A. Platelet-derived growth factor-BB and basic fibroblast growth factor directly interact in vitro with high affinity. J Biol Chem 2002;277:1284-91.

[169] De Marchis F, Ribatti D, Giampietri C, Lentini A, Faraone D, Scoccianti $\mathrm{M}$, et al. Platelet-derived growth factor inhibits basic fibroblast growth factor angiogenic properties in vitro and in vivo through its alpha receptor. Blood 2002;99:2045-53.

[170] Perollet C, Han ZC, Savona C, Caen JP, Bikfalvi A. Platelet factor 4 modulates fibroblast growth factor 2 (FGF-2) activity and inhibits FGF-2 dimerization. Blood 1998;91:3289-99.

[171] Lozano RM, Redondo-Horcajo M, Jimenez MA, Zilberberg L, Cuevas P, Bikfalvi A, et al. Solution structure and interaction with basic and acidic fibroblast growth factor of a 3-kDa human platelet factor-4 fragment with antiangiogenic activity. J Biol Chem 2001;276:35723-34

[172] Chadderton NS, Stringer SE. Interaction of platelet factor 4 with fibroblast growth factor 2 is stabilised by heparan sulphate. Int $\mathbf{J}$ Biochem Cell Biol 2003;35:1052-5.

[173] Brown KJ, Parish CR. Histidine-rich glycoprotein and platelet factor 4 mask heparan sulfate proteoglycans recognized by acidic and basic fibroblast growth factor. Biochemistry 1994;33:13918-27.

[174] Moscatelli D, Presta M, Joseph-Silverstein J, Rifkin DB. Both normal and tumor cells produce basic fibroblast growth factor. J Cell Physiol 1986;129:273-6.

[175] Presta M, Moscatelli D, Joseph-Silverstein J, Rifkin DB. Purification from a human hepatoma cell line of a basic fibroblast growth factorlike molecule that stimulates capillary endothelial cell plasminogen activator production, DNA synthesis, and migration. Mol Cell Biol 1986;6:4060-6.

[176] Kandel J, Bossy-Wetzel E, Radvanyi F, Klagsbrun M, Folkman J, Hanahan D. Neovascularization is associated with a switch to the export of bFGF in the multistep development of fibrosarcoma. Cell 1991;66:1095-104.

[177] Wang Y, Becker D. Antisense targeting of basic fibroblast growth factor and fibroblast growth factor receptor-1 in human melanomas blocks intratumoral angiogenesis and tumor growth. Nat Med 1997;3:887-93.

[178] Singh RK, Gutman M, Bucana CD, Sanchez R, Llansa N, Fidler IJ. Interferons alpha and beta down-regulate the expression of basic fibroblast growth factor in human carcinomas. Proc Natl Acad Sci USA 1995;92:4562-6.

[179] Baird A, Mormede P, Bohlen P. Immunoreactive fibroblast growth factor (FGF) in a transplantable chondrosarcoma: inhibition of tumor growth by antibodies to FGF. J Cell Biochem 1986;30:79-85.

[180] Gross JL, Herblin WF, Dusak BA, Czerniak P, Diamond MD, Sun T, et al. Effects of modulation of basic fibroblast growth factor on tumor growth in vivo. J Natl Cancer Inst 1993;85:121-31.

[181] Hori A, Sasada R, Matsutani E, Naito K, Sakura Y, Fujita T, et al. Suppression of solid tumor growth by immunoneutralizing monoclonal antibody against human basic fibroblast growth factor. Cancer Res 1991;51:6180-4.

[182] Compagni A, Wilgenbus P, Impagnatiello MA, Cotten M, Christofori G. Fibroblast growth factors are required for efficient tumor angiogenesis. Cancer Res 2000;60:7163-9.

[183] Rak J, Kerbel RS. bFGF and tumor angiogenesis-back in the limelight? Nat Med 1997;3:1083-4.

[184] Aigner A, Butscheid M, Kunkel P, Krause E, Lamszus K, Wellstein A, et al. An FGF-binding protein (FGF-BP) exerts its biological function by parallel paracrine stimulation of tumor cell and endothelial cell proliferation through FGF-2 release. Int J Cancer 2001;92: 510-7.

[185] Souttou B, Gamby C, Crepin M, Hamelin R. Tumoral progression of human breast epithelial cells secreting FGF2 and FGF4. Int J Cancer 1996;68:675-81.

[186] Polnaszek N, Kwabi-Addo B, Peterson LE, Ozen M, Greenberg NM, Ortega S, et al. Fibroblast growth factor 2 promotes tumor progression in an autochthonous mouse model of prostate cancer. Cancer Res 2003;63:5754-60.

[187] Coltrini D, Gualandris A, Nelli EE, Parolini S, Molinari-Tosatti MP, Quarto N, et al. Growth advantage and vascularization induced by basic fibroblast growth factor overexpression in endometrial HEC-1B cells: an export-dependent mechanism of action. Cancer Res 1995;55:4729-38.

[188] Konerding MA, Fait E, Dimitropoulou C, Malkusch W, Ferri C, Giavazzi R, et al. Impact of fibroblast growth factor-2 on tumor microvascular architecture. A tridimensional morphometric study. Am J Pathol 1998;152:1607-16.

[189] Giavazzi R, Giuliani R, Coltrini D, Bani MR, Ferri C, Sennino B, et al. Modulation of tumor angiogenesis by conditional expression of fibroblast growth factor- 2 affects early but not established tumors. Cancer Res 2001;61:309-17.

[190] Rousseau B, Larrieu-Lahargue F, Javerzat S, Guilhem-Ducleon F, Beermann F, Bikfalvi A. The tyrp1-Tag/tyrp1-FGFR1-DN bigenic mouse: a model for selective inhibition of tumor development, angiogenesis, and invasion into the neural tissue by blockade of fibroblast growth factor receptor activity. Cancer Res 2004;64: 2490-5.

[191] Yamayoshi T, Nagayasu T, Matsumoto K, Abo T, Hishikawa Y, Koji T. Expression of keratinocyte growth factor/fibroblast growth factor7 and its receptor in human lung cancer: correlation with tumour proliferative activity and patient prognosis. J Pathol 2004;204: 110-8.

[192] Weidner N. Intratumor microvessel density as a prognostic factor in cancer. Am J Pathol 1995;147:9-19. 
[193] Hollingsworth HC, Kohn EC, Steinberg SM, Rothenberg ML, Merino MJ. Tumor angiogenesis in advanced stage ovarian carcinoma. Am J Pathol 1995;147:33-41.

[194] Vacca A, Ribatti D, Ruco L, Giacchetta F, Nico B, Quondamatteo F, et al. Angiogenesis extent and macrophage density increase simultaneously with pathological progression in B-cell non-Hodgkin's lymphomas. Br J Cancer 1999;79:965-70.

[195] Padro T, Ruiz S, Bieker R, Burger H, Steins M, Kienast J, et al. Increased angiogenesis in the bone marrow of patients with acute myeloid leukemia. Blood 2000;95:2637-44.

[196] Folkman J. Angiogenesis-dependent diseases. Semin Oncol 2001;28: $536-42$.

[197] Ferrara N, Alitalo K. Clinical applications of angiogenic growth factors and their inhibitors. Nat Med 1999;5:1359-64.

[198] Ria R, Portaluri M, Russo F, Cirulli T, Pietro GD, Bambace S, et al. Serum levels of angiogenic cytokines decrease after antineoplastic radiotherapy. Cancer Lett 2004;216:103-7.

[199] Nguyen M, Watanabe H, Budson AE, Richie JP, Hayes DF, Folkman J. Elevated levels of an angiogenic peptide, basic fibroblast growth factor, in the urine of patients with a wide spectrum of cancers. J Natl Cancer Inst 1994;86:356-61.

[200] Dirix LY, Vermeulen PB, Pawinski A, Prove A, Benoy I, De Pooter C, et al. Elevated levels of the angiogenic cytokines basic fibroblast growth factor and vascular endothelial growth factor in sera of cancer patients. Br J Cancer 1997;76:238-43.

[201] Poon RT, Fan ST, Wong J. Clinical implications of circulating angiogenic factors in cancer patients. J Clin Oncol 2001;19:1207-25.

[202] Li VW, Folkerth RD, Watanabe H, Yu C, Rupnick M, Barnes P, et al. Microvessel count and cerebrospinal fluid basic fibroblast growth factor in children with brain tumours. Lancet 1994;344:82-6.

[203] Salgado R, Benoy I, Vermeulen P, van Dam P, Van Marck E, Dirix L. Circulating basic fibroblast growth factor is partly derived from the tumour in patients with colon, cervical and ovarian cancer. Angiogenesis 2004;7:29-32.

[204] Kuwabara K, Ogawa S, Matsumoto M, Koga S, Clauss M, Pinsky DJ, et al. Hypoxia-mediated induction of acidic/basic fibroblast growth factor and platelet-derived growth factor in mononuclear phagocytes stimulates growth of hypoxic endothelial cells. Proc Natl Acad Sci USA 1995;92:4606-10.

[205] Baird A, Mormede P, Bohlen P. Immunoreactive fibroblast growth factor in cells of peritoneal exudate suggests its identity with macrophage-derived growth factor. Biochem Biophys Res Commun 1985;126:358-64.

[206] Blotnick S, Peoples GE, Freeman MR, Eberlein TJ, Klagsbrun M. T lymphocytes synthesize and export heparin-binding epidermal growth factor-like growth factor and basic fibroblast growth factor, mitogens for vascular cells and fibroblasts: differential production and release by CD4+ and CD8+ T cells. Proc Natl Acad Sci USA 1994;91:2890-4.

[207] Peoples GE, Blotnick S, Takahashi K, Freeman MR, Klagsbrun M, Eberlein TJ. T lymphocytes that infiltrate tumors and atherosclerotic plaques produce heparin-binding epidermal growth factor-like growth factor and basic fibroblast growth factor: a potential pathologic role. Proc Natl Acad Sci USA 1995;92:6547-51.

[208] Ribatti D, Crivellato E, Candussio L, Vacca A, Nico B, Benagiano V, et al. Angiogenic activity of rat mast cells in the chick embryo chorioallantoic membrane is down-regulated by treatment with recombinant human alpha-2a interferon and partly mediated by fibroblast growth factor-2. Haematologica 2002;87:465-71.

[209] Gloe T, Sohn HY, Meininger GA, Pohl U. Shear stress-induced release of basic fibroblast growth factor from endothelial cells is mediated by matrix interaction via integrin alpha(v)beta3. J Biol Chem 2002;277:23453-8.

[210] Hartnett ME, Garcia CM, D'Amore PA. Release of bFGF, an endothelial cell survival factor, by osmotic shock. Invest Ophthalmol Vis Sci 1999;40:2945-51.
[211] Cozzolino F, Torcia M, Lucibello M, Morbidelli L, Ziche M, Platt J, et al. Interferon-alpha and interleukin 2 synergistically enhance basic fibroblast growth factor synthesis and induce release, promoting endothelial cell growth. J Clin Invest 1993;91:2504-12.

[212] Lee HT, Lee JG, Na M, Kay EP. FGF-2 induced by interleukin-1 beta through the action of phosphatidylinositol 3-kinase mediates endothelial mesenchymal transformation in corneal endothelial cells. J Biol Chem 2004;279:32325-32.

[213] Walford G, Loscalzo J. Nitric oxide in vascular biology. J Thromb Haemost 2003;1:2112-8.

[214] Morbidelli L, Donnini S, Ziche M. Role of nitric oxide in the modulation of angiogenesis. Curr Pharm Des 2003;9:521-30.

[215] Ziche M, Morbidelli L, Choudhuri R, Zhang HT, Donnini S, Granger HJ, et al. Nitric oxide synthase lies downstream from vascular endothelial growth factor-induced but not basic fibroblast growth factor-induced angiogenesis. J Clin Invest 1997;99:2625-34.

[216] Ziche M, Parenti A, Ledda F, Dell'Era P, Granger HJ, Maggi CA, et al. Nitric oxide promotes proliferation and plasminogen activator production by coronary venular endothelium through endogenous bFGF. Circ Res 1997;80:845-52.

[217] Gajdusek CM, Carbon S. Injury-induced release of basic fibroblast growth factor from bovine aortic endothelium. J Cell Physiol 1989;139:570-9.

[218] Pugh CW. Oxygen sensing in cancer. Ann Med 2003;35:380-90.

[219] Li J, Shworak NW, Simons M. Increased responsiveness of hypoxic endothelial cells to FGF2 is mediated by HIF-1alpha-dependent regulation of enzymes involved in synthesis of heparan sulfate FGF2-binding sites. J Cell Sci 2002;115:1951-9.

[220] Wang L, Xiong M, Che D, Liu S, Hao C, Zheng X. The effect of hypoxia on expression of basic fibroblast growth factor in pulmonary vascular pericytes. J Tongji Med Univ 2000;20:265-7.

[221] Tiefenbacher CP, Chilian WM. Basic fibroblast growth factor and heparin influence coronary arteriolar tone by causing endotheliumdependent dilation. Cardiovasc Res 1997;34:411-7.

[222] Reuss B, Dono R, Unsicker K. Functions of fibroblast growth factor (FGF)-2 and FGF-5 in astroglial differentiation and blood-brain barrier permeability: evidence from mouse mutants. J Neurosci 2003;23:6404-12.

[223] Zhang H, Issekutz AC. Growth factor regulation of neutrophilendothelial cell interactions. J Leukoc Biol 2001;70:225-32.

[224] Barleon B, Sozzani S, Zhou D, Weich HA, Mantovani A, Marme D. Migration of human monocytes in response to vascular endothelial growth factor (VEGF) is mediated via the VEGF receptor flt-1. Blood 1996;87:3336-43.

[225] Leali D, Dell'Era P, Stabile H, Sennino B, Chambers AF, Naldini A, et al. Osteopontin (Eta-1) and fibroblast growth factor-2 cross-talk in angiogenesis. J Immunol 2003;171:1085-93.

[226] Wempe F, Lindner V, Augustin HG. Basic fibroblast growth factor (bFGF) regulates the expression of the $\mathrm{CC}$ chemokine monocyte chemoattractant protein-1 (MCP-1) in autocrine-activated endothelial cells. Arterioscler Thromb Vasc Biol 1997;17:2471-8.

[227] Kage K, Fujita N, Oh-hara T, Ogata E, Fujita T, Tsuruo T. Basic fibroblast growth factor induces cyclooxygenase-2 expression in endothelial cells derived from bone. Biochem Biophys Res Commun 1999;254:259-63.

[228] Shaw JP, Chuang N, Yee H, Shamamian P. Polymorphonuclear neutrophils promote rFGF-2-induced angiogenesis in vivo. J Surg Res 2003;109:37-42.

[229] Zhang H, Issekutz AC. Down-modulation of monocyte transendothelial migration and endothelial adhesion molecule expression by fibroblast growth factor: reversal by the anti-angiogenic agent SU6668. Am J Pathol 2002;160:2219-30.

[230] Kitayama J, Nagawa H, Yasuhara H, Tsuno N, Kimura W, Shibata Y, et al. Suppressive effect of basic fibroblast growth factor on transendothelial emigration of CD4(+) T-lymphocyte. Cancer Res 1994;54:4729-33. 
[231] Pendurthi UR, Williams JT, Rao LV. Acidic and basic fibroblast growth factors suppress transcriptional activation of tissue factor and other inflammatory genes in endothelial cells. Arterioscler Thromb Vasc Biol 1997;17:940-6.

[232] Griffioen AW, Damen CA, Blijham GH, Groenewegen G. Tumor angiogenesis is accompanied by a decreased inflammatory response of tumor-associated endothelium. Blood 1996;88:667-73.

[233] Mantovani A, Allavena P, Sica A. Tumour-associated macrophages as a prototypic type II polarised phagocyte population: role in tumour progression. Eur J Cancer 2004;40:1660-7.

[234] Post MJ, Laham R, Sellke FW, Simons M. Therapeutic angiogenesis in cardiology using protein formulations. Cardiovasc Res 2001;49: 522-31.

[235] Sellke FW, Laham RJ, Edelman ER, Pearlman JD, Simons M. Therapeutic angiogenesis with basic fibroblast growth factor: technique and early results. Ann Thorac Surg 1998;65:1540-4.

[236] Laham RJ, Sellke FW, Edelman ER, Pearlman JD, Ware JA, Brown $\mathrm{DL}$, et al. Local perivascular delivery of basic fibroblast growth factor in patients undergoing coronary bypass surgery: results of a phase I randomized, double-blind, placebo-controlled trial. Circulation 1999;100:1865-71.

[237] Unger EF, Goncalves L, Epstein SE, Chew EY, Trapnell CB, Cannon III RO, et al. Effects of a single intracoronary injection of basic fibroblast growth factor in stable angina pectoris. Am J Cardiol 2000;85:1414-9.

[238] Simons M, Annex BH, Laham RJ, Kleiman N, Henry T, Dauerman H, et al. Pharmacological treatment of coronary artery disease with recombinant fibroblast growth factor-2: double-blind, randomized, controlled clinical trial. Circulation 2002;105:788-93.

[239] Lazarous DF, Unger EF, Epstein SE, Stine A, Arevalo JL, Chew EY, et al. Basic fibroblast growth factor in patients with intermittent claudication: results of a phase I trial. J Am Coll Cardiol 2000;36: 1239-44.

[240] Lederman RJ, Mendelsohn FO, Anderson RD, Saucedo JF, Tenaglia AN, Hermiller JB, et al. Therapeutic angiogenesis with recombinant fibroblast growth factor- 2 for intermittent claudication (the TRAFFIC study): a randomised trial. Lancet 2002;359:2053-8.

[241] Lopez JJ, Edelman ER, Stamler A, Hibberd MG, Prasad P, Caputo $\mathrm{RP}$, et al. Basic fibroblast growth factor in a porcine model of chronic myocardial ischemia: a comparison of angiographic, echocardiographic and coronary flow parameters. J Pharmacol Exp Ther 1997;282:385-90.
[242] Tabata H, Silver M, Isner JM. Arterial gene transfer of acidic fibroblast growth factor for therapeutic angiogenesis in vivo: critical role of secretion signal in use of naked DNA. Cardiovasc Res 1997;35:470-9.

[243] Freedman SB, Isner JM. Therapeutic angiogenesis for coronary artery disease. Ann Intern Med 2002;136:54-71.

[244] Comerota AJ, Throm RC, Miller KA, Henry T, Chronos N, Laird J, et al. Naked plasmid DNA encoding fibroblast growth factor type 1 for the treatment of end-stage unreconstructible lower extremity ischemia: preliminary results of a phase I trial. J Vasc Surg 2002;35: 930-6.

[245] Kasahara H, Tanaka E, Fukuyama N, Sato E, Sakamoto H, Tabata Y, et al. Biodegradable gelatin hydrogel potentiates the angiogenic effect of fibroblast growth factor 4 plasmid in rabbit hindlimb ischemia. J Am Coll Cardiol 2003;41:1056-62.

[246] Grines C, Rubanyi GM, Kleiman NS, Marrott P, Watkins MW. Angiogenic gene therapy with adenovirus 5 fibroblast growth factor-4 (Ad5FGF-4): a new option for the treatment of coronary artery disease. Am J Cardiol 2003;92:24N-31N.

[247] Syed IS, Sanborn TA, Rosengart TK. Therapeutic angiogenesis: a biologic bypass. Cardiology 2004;101:131-43.

[248] Cao R, Brakenhielm E, Pawliuk R, Wariaro D, Post MJ, Wahlberg E, et al. Angiogenic synergism, vascular stability and improvement of hind-limb ischemia by a combination of PDGF-BB and FGF-2. Nat Med 2003;9:604-13.

[249] Senn HJ, Orth M, Fitzke E, Wieland H, Gerok W. Gangliosides in normal human serum. Concentration, pattern and transport by lipoproteins. Eur J Biochem 1989;181:657-62.

[250] McCrohan MB, Huang SW, Sleasman JW, Klein PA, Kao KJ. Plasma thrombospondin as an indicator of intravascular platelet activation in patients with vasculitis. Thromb Haemost 1987;58:850-2.

[251] Latini R, Maggioni AP, Peri G, Gonzini L, Lucci D, Mocarelli P, et al. Prognostic significance of the long pentraxin PTX3 in acute myocardial infarction. Circulation 2004;110:2349-54.

[252] Sahni A, Odrljin T, Francis CW. Binding of basic fibroblast growth factor to fibrinogen and fibrin. J Biol Chem 1998;273:7554-9.

[253] Gleich LL, Srivastava L, Gluckman JL. Plasma platelet-derived growth factor: preliminary study of a potential marker in head and neck cancer. Ann Otol Rhinol Laryngol 1996;105:710-2.

[254] Placanica G, Migliau G, Nasso G, Rosso R, Tallarico D. Short-term effect of exercise on platelet factor 4 in normal subjects and in patients with coronary artery disease. Cardiologia 1999;44:993-6. 